
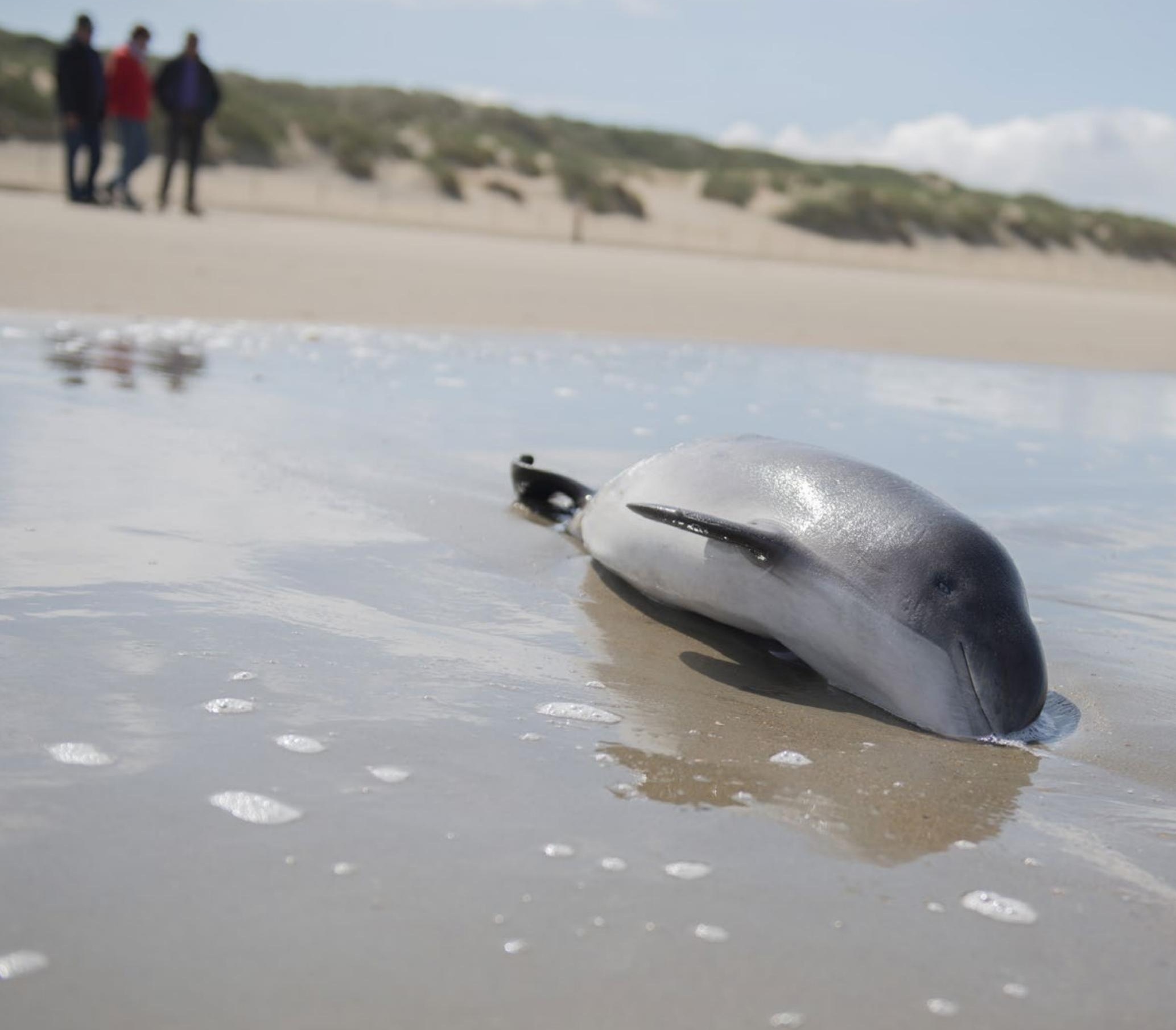

\title{
Postmortaal onderzoek van bruinvissen (Phocoena phocoena) uit Nederlandse wateren, 2019
}

Biologische gegevens, gezondheidsstatus en doodsoorzaken 

Postmortaal onderzoek van bruinvissen (Phocoena phocoena) uit Nederlandse wateren, 2019 
Dit Technical report is gemaakt conform het Kwaliteitsmanagementsysteem (KMS) van de unit Wettelijke Onderzoekstaken Natuur \& Milieu, onderdeel van Wageningen University \& Research.

De WOT Natuur \& Milieu voert wettelijke onderzoekstaken uit op het beleidsterrein natuur en milieu. Deze taken worden uitgevoerd om een wettelijke verantwoordelijkheid van de Minister van Landbouw, Natuur en Voedselkwaliteit (LNV) te ondersteunen. We zorgen voor rapportages en data voor (inter)nationale verplichtingen op het gebied van agromilieu, biodiversiteit en bodeminformatie, en werken mee aan producten van het Planbureau voor de Leefomgeving zoals de Balans van de Leefomgeving.

\section{Disclaimer WOt-publicaties}

De reeks 'WOt-technical reports' bevat onderzoeksresultaten van projecten die kennisorganisaties voor de unit Wettelijke Onderzoekstaken Natuur \& Milieu hebben uitgevoerd.

WOt-technical report 184 is het resultaat van onderzoek gefinancierd door het ministerie van Landbouw, Natuur en Voedselkwaliteit (LNV). 


\section{Postmortaal onderzoek van bruinvissen (Phocoena phocoena) uit Nederlandse wateren, 2019}

Biologische gegevens, gezondheidsstatus en doodsoorzaken

Lonneke L. IJsseldijk ${ }^{1}$, Marja J.L. Kik ${ }^{1}$, Linde van Schalkwijk ${ }^{1}$ \& Andrea Gröne ${ }^{1}$

1 Afdeling Pathologie, Departement Biomolecular Health Science, Faculteit Diergeneeskunde, Universiteit Utrecht

Projectnummer WOT-04-009-047.05

Wettelijke Onderzoekstaken Natuur \& Milieu

Wageningen, augustus 2020

WOt-technical report 184

ISSN 2352-2739

DOI: $10.18174 / 523708$ 


\title{
Referaat
}

IJsseldijk, L.L., M.J.L. Kik, L. van Schalkwijk \& A. Gröne (2020). Postmortaal onderzoek van bruinvissen (Phocoena phocoena) uit Nederlandse wateren, 2019. Biologische gegevens, gezondheidsstatus en doodsoorzaken. Wettelijke Onderzoekstaken Natuur \& Milieu, WOt-technical report 184. 54 blz.; 15 fig.; 3 tab.; 51 ref; 3 Bijlagen.

In dit jaarrapport worden de resultaten gepresenteerd van pathologisch onderzoek aan bruinvissen in 2019. Eén van de hoofddoelen van het onderzoek is het kwantificeren van sterfte van bruinvissen door menselijk toedoen. In 2019 zijn 57 dode bruinvissen onderzocht; 31 mannelijke en 26 vrouwelijke, 22 volwassen, 24 juveniel en 11 neonaat. Er werden daarnaast 6 foetussen gevonden. De meeste van de onderzochte bruinvissen waren gestorven door infectieziekten (30\%) en grijze zeehond aanvallen (21\%), gevolgd door bijvangst (11\%).

Trefwoorden: bruinvissen, stranding, doodsoorzaakonderzoek, bijvangst, pathologie, histologie

\section{Abstract}

IJsseldijk, L.L., M.J.L. Kik, L. van Schalkwijk \& A. Gröne (2020). Post-mortem research on porpoises (Phocoena phocoena) from Dutch waters, 2019. Biological data, health status and causes of death. Statutory Research Tasks Unit for Nature \& the Environment (WOT Natuur \& Milieu). WOt-technical report 184. 54 p.; 15 Figs; 3 Tabs; 51 Refs; 3 Annexes.

This annual report presents the results of post-mortem examinations of porpoises in 2019. One of the main objectives of the research is to quantify human-induced causes of death. In 2019, 57 dead harbour porpoises were examined: 31 males and 26 females, 22 adults, 24 juveniles and 11 neonates. There were an additional six foetuses found. Most of the examined harbour porpoises died as a result of infectious diseases $(30 \%)$ and grey seal attacks $(21 \%)$, followed by bycatch $(11 \%)$.

Key words: harbour porpoises, stranding, cause of death, bycatch, pathology, histology

Foto omslag: Afdeling Multimedia, Faculteit Diergeneeskunde

\author{
Veterinair Pathologisch Diagnostisch Centrum \\ Afdeling Pathologie, Departement Biomolecular Health Sciences \\ Faculteit Diergeneeskunde, Universiteit Utrecht \\ Yalelaan 1, $3584 \mathrm{CL}$ Utrecht \\ Tel. (+31) 6244556 98; E-mail: L.L. IJsseldijk@uu.nl \\ www.uu.nl/strandingsonderzoek
}

Wettelijke Onderzoekstaken Natuur \& Milieu (unit binnen de rechtspersoon Stichting Wageningen Research), Postbus 47, 6700 AA Wageningen, T 03174854 71, info.wnm@wur.nl, www.wur.nl/wotnatuurenmilieu.

WOT Natuur \& Milieu is onderdeel van Wageningen University \& Research.

Dit rapport is gratis te downloaden van https://doi.org/10.18174/523708 of op www.wur.nl/wotnatuurenmilieu. De WOT Natuur \& Milieu verstrekt geen gedrukte exemplaren van rapporten.

- Overname, verveelvoudiging of openbaarmaking van deze uitgave is toegestaan mits met duidelijke bronvermelding.

- Overname, verveelvoudiging of openbaarmaking is niet toegestaan voor commerciële doeleinden en/of geldelijk gewin.

- Overname, verveelvoudiging of openbaarmaking is niet toegestaan voor die gedeelten van deze uitgave waarvan duidelijk is dat de auteursrechten liggen bij derden en/of zijn voorbehouden.

Wettelijke Onderzoekstaken Natuur \& Milieu aanvaardt geen aansprakelijkheid voor eventuele schade voortvloeiend uit het gebruik van de resultaten van dit onderzoek of de toepassing van de adviezen. 


\section{Woord vooraf}

Onderzoek naar doodsoorzaken van gestrande bruinvissen wordt in Nederland uitgevoerd bij de Faculteit Diergeneeskunde, Universiteit Utrecht (UU). Naast het doodsoorzaakonderzoek worden weefsels voor aanvullende onderzoeken verzameld, wat resulteert in tal van unieke onderzoeken aan bruinvissen in Nederland en daarbuiten. Deze rapportage behandelt alleen de in 2019 onderzochte dode bruinvissen die in het kader van de Wettelijke Onderzoekstaak Natuur \& Milieu zijn bestudeerd. Om dit onderzoek in de toekomst voort te kunnen blijven zetten, zullen wij afhankelijk zijn van het vrijwillige strandingsnetwerk, waarvan we de vrijwilligers heel dankbaar zijn voor hun inzet en enthousiasme in het melden en verzamelen van gestrande bruinvissen. Hieronder vallen vrijwilligers die aangesloten zijn bij een tiental organisaties, onder andere (in alfabetische volgorde): Dierenambulance Den Haag, Dierenambulance de Waadhoeke, Ecomare, Eerste Hulp Bij Zeezoogdieren (EHBZ), Gul Egmond B.V., Koninklijke Nederlandse Redding Maatschappij (KNRM), Natuurcentrum Ameland, Stichting Dierenlot, Stichting ReddingsTeam Zeedieren (RTZ), Stichting SOS Dolfijn, Stichting Zeehondenopvang Terschelling, Wageningen University \& Research, Zeehondencentrum Pieterburen, Zeehondenopvang ASeal en Zeezoogdierenhulp kop van Goeree. Daarnaast hebben gemeentes, strandvonders en politie bijdragen geleverd bij het melden, verzamelen en transporteren van gestrande dieren.

Utrecht, april 2020

Lonneke IJsseldijk 



\section{Inhoud}

$\begin{array}{ll}\text { Woord vooraf } & 5\end{array}$

$\begin{array}{lr}\text { Samenvatting } & 9\end{array}$

$\begin{array}{lr}\text { Summary } & 11\end{array}$

$\begin{array}{llr}1 & \text { Inleiding } & 13\end{array}$

2 De opdracht $r$

$\begin{array}{llr}3 & \text { Methoden } & 17\end{array}$

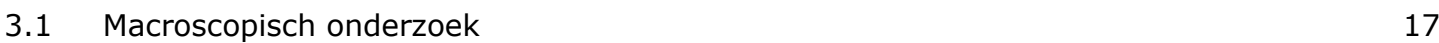

$\begin{array}{ll}3.2 \text { Histologisch onderzoek } & 17\end{array}$

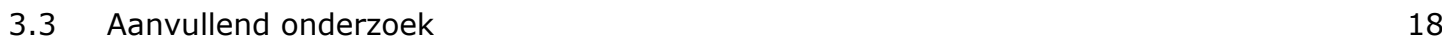

3.4 Doodsoorzaak categorieën 19

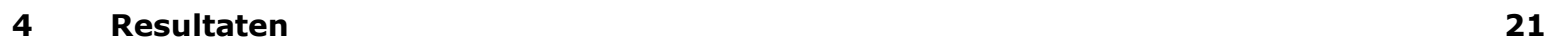

$\begin{array}{lll}4.1 & \text { Herkomst en biologische gegevens } & 21\end{array}$

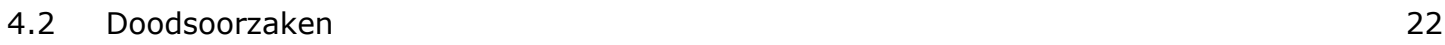

4.2.1 Infectieziekten $\quad 23$

$\begin{array}{ll}4.2 .2 \text { Bijvangst } & 24\end{array}$

4.2.3 Grijze zeehond aanval 26

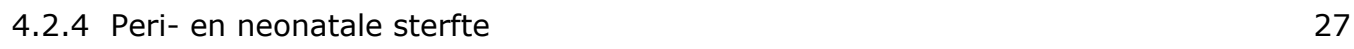

$\begin{array}{ll}4.2 .5 \text { Vermagering } & 27\end{array}$

$\begin{array}{ll}4.2 .6 \text { Overig } & 27\end{array}$

$\begin{array}{lll}4.3 & \text { Aanvullende testen } & 29\end{array}$

4.3.1 Bacteriologie en mycologie $\quad 29$

$\begin{array}{ll}\text { 4.3.2 Parasitologie } & 30\end{array}$

5 Discussie en conclusies $\quad 31$

$\begin{array}{lr}\text { Literatuur } & 39\end{array}$

$\begin{array}{lr}\text { Verantwoording } & 43\end{array}$

$\begin{array}{lr}\text { Begrippenlijst } & 45\end{array}$

$\begin{array}{lll}\text { Bijlage } 1 & \text { Doodsoorzaak categorieën } & 47\end{array}$

Bijlage 2 Basisgegevens bruinvissen 2019

$\begin{array}{lll}\text { Bijlage } 3 & \text { Extra figuren discussie } & 51\end{array}$ 



\section{Samenvatting}

Postmortaal onderzoek van bruinvissen, en andere gestrande zeezoogdieren, vindt sinds december 2008 plaats bij het Veterinair Pathologisch Diagnostisch Centrum (VPDC) van de Afdeling Pathologie, Faculteit Diergeneeskunde, Universiteit Utrecht, in opdracht van het Ministerie van Landbouw, Natuur en Voedselkwaliteit (LNV). Dit is tot stand gekomen als gevolg van het 'Agreement on the Conservation of Small Cetaceans of the Baltic and North Seas (ASCOBANS)', dat sinds 1991 van kracht is.

Nederland heeft de verplichting zich in te zetten voor de instandhouding van de bruinvispopulatie in haar wateren. Hierbij hoort de opzet van een efficiënt systeem voor het verzamelen van gestrande dieren en het uitvoeren van volledig postmortaal onderzoek om (indien mogelijk) een doodsoorzaak vast te stellen, weefselmonsters te verzamelen voor verder onderzoek en de voedselsamenstelling te documenteren. Sinds 2016 is het postmortaal onderzoek geborgd in de Wettelijke Onderzoekstaak (WOT) 'Monitor bruinvis'. Eén van de hoofddoelen van het onderzoek is het achterhalen van het aantal door menselijk toedoen gestorven bruinvissen. Hierbij kan gedacht worden aan bijvoorbeeld bijvangst. Daarnaast worden de biologische gegevens van de onderzochte bruinvissen gedocumenteerd en weefsels veiliggesteld voor aanvullende onderzoeken.

In 2019 zijn in totaal 22 volwassen bruinvissen onderzocht, 24 juveniele dieren en 11 neonaten. De verdeling naar geslacht was 31 man en 26 vrouw. De verdeling man/vrouw binnen de verschillende leeftijdsklasse was niet geheel gelijk: er werden meer mannelijke juveniele dieren gevonden en meer vrouwelijke adulte. Daarnaast werden zes foetussen gevonden; twee vrouwtjes en vier mannetjes.

Postmortaal onderzoek heeft uitgewezen dat de meeste van de onderzochte dieren strandden als gevolg van een infectieziekte $(n=17,30 \%)$ en als direct of indirect gevolg van een grijze zeehond aanval $(n=12,21 \%)$. Bijvangst was de vermoedelijke doodsoorzaak van zes van de onderzochte dieren (11\%). Dit kon met zekerheid worden gesteld bij één dier, waarbij de bijvangst waargenomen was, en was op basis van de sectie hoogstwaarschijnlijk bij drie bruinvissen en waarschijnlijk bij twee. Daarnaast stierven elf pasgeboren/jonge bruinvissen als gevolg van problemen bij de geboorte en/of onvoldoende voedselopname (19\%), vier andere bruinvissen als gevolg van ernstige vermagering (7\%), twee volwassen vrouwtjes tijdens de bevalling (4\%) en twee bruinvissen door trauma (4\%). Bij één geëuthanaseerde bruinvis kon geen oorzaak voor het levend stranden worden gevonden ( $2 \%)$ en de doodsoorzaak van twee bruinvissen bleef onduidelijk (4\%). 



\section{Summary}

Since December 2008 the Veterinary Pathology Diagnostic Centre at Utrecht University's Department of Pathology has been carrying out post-mortem examinations of harbour porpoises and other stranded cetaceans. These examinations are commissioned by the Ministry of Agriculture, Nature and Food Quality under the Agreement on the Conservation of Small Cetaceans of the Baltic and North Seas (ASCOBANS), which came into force in 1991.

As a signatory to ASCOBANS, the Netherlands has undertaken to work to achieve a favourable conservation status for harbour porpoises in its national waters. This includes setting up an efficient system for retrieving stranded animals and conducting full post-mortem examinations to establish (if possible) the cause of death, to collect tissue samples for further studies and to collect stomachs for diet analysis. Since 2016 the post-mortem examinations have been conducted under the 'Harbour Porpoise Monitoring' Statutory Research Task. One of the main objectives of the research is to establish the number of harbour porpoise deaths that are caused by human activities, such as bycatch. In addition, the biological data on the harbour porpoises are recorded and tissue samples archived for further study.

In 2019 a total of 57 harbour porpoises were examined: 22 adults, 24 juveniles and 11 neonates; 31 males and 26 females. The sex ratios within the different age classes were not exactly the same: more male juveniles were found and more female adults. In addition, 6 foetuses were found, two females and four males.

Post-mortem examinations showed that most of the animals stranded as a result of an infectious disease $(n=17,30 \%)$ or as a direct or indirect consequence of attacks by grey seal $(n=12,21 \%)$. Bycatch was the probable cause of death of 6 of the examined animals (11\%). This could be established with certainty for one animal, as the bycatch was observed, and was highly probable for three harbour porpoises and probable for two. In addition, 11 newborn/young harbour porpoises died as a result of problems during birth and/or insufficient food intake (19\%), 4 other harbour porpoises died from severe emaciation (7\%), 2 adult females died during giving birth (4\%) and 2 harbour porpoises died from trauma (4\%). One harbour porpoise was stranded alive (2\%) and euthanised, but no cause of stranding could be detected. The cause of death of 2 other harbour porpoises remains unclear. 



\section{$1 \quad$ Inleiding}

De bruinvis (Phocoena phocoena) is een veel voorkomende soort in de Noordzee (Camphuysen \& Peet 2006; Geelhoed et al. 2013, Geelhoed \& Scheidat 2018) en grootschalige tellingen hebben het aantal rond de 350.000 individuen geschat (Hammond et al. 2002; 2017), waarvan -afhankelijk van het seizoen- tussen de 26.000 en $\mathbf{8 5 . 0 0 0}$ dieren in het Nederlands deel van de Noordzee voorkomen (Geelhoed et al. 2013, Geelhoed \& Scheidat 2018). Dit is een groot aantal in vergelijking met tientallen jaren geleden en de bruinvis is tussen 1960-1980 zelfs helemaal weg geweest (Camphuysen 2004; Camphuysen 2011; Haelters et al. 2011). Waarnemingen begonnen echter vanaf de jaren negentig weer sterk toe te nemen (Camphuysen \& Siemensma 2011) en dit ging gepaard met een toename in het aantal strandingen.

Bruinvissen zijn beschermd binnen zowel nationale als internationale regelgeving en verdragen (bijvoorbeeld: ASCOBANS; Europese Habitatrichtlijn; Kaderrichtlijn Mariene Strategie en het Gemeenschappelijk Visserijbeleid; OSPAR Conventie). Voor de Habitatrichtlijn en ook binnen de ASCOBANS-overeenkomst heeft Nederland de verplichting om zich in te zetten voor de instandhouding van de bruinvispopulatie in Nederlandse wateren (Richtlijn 92/43/EEG en ASCOBANS Agreement Text, 1992). Binnen ASCOBANS is gesteld dat het percentage 'antropogene verwijdering' $<1.7 \%$ van de populatie dient te liggen om geen significant negatieve effecten op de bruinvispopulatie te hebben en er wordt gestreefd naar $0 \%$.

Bruinvissen staan bovenaan de voedselketen in de Noordzee en worden gezien als indicatorsoort voor hun leefgebied (Moore 2008; Bossart 2011, Peltier et al. 2013). Veranderingen binnen het leefgebied zullen een effect hebben op individuen en daarmee uiteindelijk de populatie. Door het grote aantal waarin bruinvissen voorkomen en de grote kans dat gestrande dieren worden gevonden en gerapporteerd, kunnen veranderingen in het aantal strandingen en de doodsoorzaken tijdig worden opgemerkt, waardoor adequaat reageren mogelijk wordt. Dit is vooral belangrijk wanneer bepaalde bedreigingen toenemen of wanneer er nieuwe bedreigingen ontstaan. Om die reden is een efficiënt systeem nodig voor het verzamelen van gestrande dieren en het uitvoeren van volledig postmortaal onderzoek om (indien mogelijk) een doodsoorzaak vast te stellen, weefselmonsters te verzamelen voor verder onderzoek en de voedselsamenstelling te documenteren.

Een dergelijk efficiënt strandingsnetwerk is in Nederland aanwezig (data zichtbaar op https://www.walvisstrandingen.nl/), maar ook in andere omringende Noordzeelanden. In 2018 is vanuit het Wind op Zee Ecologisch Programma van Rijkswaterstaat een onderzoek uitbesteed aan de Universiteit Utrecht (UU) met betrekking tot analyse van bruinvisstrandingen rond de Noordzee. Strandingsgegevens van 1990-2017 verzameld door de nationale strandingsnetwerken van Schotland, Engeland, België, Nederland, Duitsland en Denemarken werden in één database gezet en deze database is geanalyseerd om spatio-temporale trends in stranding frequenties en biologische kenmerken van de gestrande bruinvissen te onderzoeken. De belangrijkste conclusie van deze analyse was dat het strandingsaantal in voornamelijk de zuidelijke Noordzee significant gestegen is sinds 2004, terwijl dat in andere gebieden rond de Noordzee stabiel bleef. Daarmee werd tevens geconcludeerd dat het hoogste aantal dode bruinvissen op de Nederlandse kust werd gevonden en dit omvatte voornamelijk juveniele mannelijke dieren. De data-analyse zoals uitgevoerd liet niet toe om verdere uitspraken te doen over het hoe en waarom, omdat aanvullende gegevens over de gezondheid van de gestrande dieren in die studie niet konden worden meegenomen (IJsseldijk et al. 2020).

De Noordzee is een wereldwijde hotspot van antropogene activiteiten, waar bijna alle bekende antropogene stressoren voorkomen en elkaar overlappen (Halpern et al. 2008; 2015). Bruinvissen in de Noordzee worden beïnvloed door antropogene verstoring zoals visserijactiviteiten (bijvangst en concurrentie (Leeney et al. 2008; IJsseldijk et al. 2018), chemische vervuiling (Pierce et al. 2008; Weijs et al. 2010; Jepson et al. 2016; Van den Heuvel-Greve et al. in prep), geluidsoverlast door scheepvaart (Wisniewska et al. 2018), seismische surveys en onderwaterexplosies (von Benda- 
Beckmann et al. 2015; De Haan et al. 2015; Aarts et al. 2016), en meer recent, de exponentiële groei van industriële offshore-activiteiten voor de grootschalige bouw van windparken (Madsen et al. 2006; Gilles et al. 2009). Dit benadrukt, nogmaals, de noodzaak om door middel van de verkregen informatie tijdens postmortaal onderzoek dieper in te gaan op de gezondheidsstatus van de bruinvissen die in Nederland stranden en eventuele veranderingen daarbinnen over tijd en locaties te lokaliseren.

Postmortaal onderzoek van bruinvissen, en andere gestrande walvisachtigen, vindt sinds december 2008 plaats bij het Veterinair Pathologisch Diagnostisch Centrum (VPDC) van de Afdeling Pathologie, Faculteit Diergeneeskunde, Universiteit Utrecht (UU), in opdracht van het Ministerie van Landbouw, Natuur en Voedselkwaliteit (LNV). Sinds 2016 behoort het postmortaal onderzoek bij de Wettelijke Onderzoekstaken Natuur \& Milieu, onderdeel van Wageningen University \& Research. Van 2016 tot en met 2020 is financiering gegarandeerd, onder toezicht van Wageningen Marine Research (WMR). In dit jaarrapport wordt een overzicht gegeven van het in 2019 uitgevoerde postmortaal onderzoek van bruinvissen. Tevens wordt er in de discussie extra aandacht besteed aan een vergelijking tussen de doodsoorzaken over de gehele onderzoeksperiode (sinds 2008). 


\section{De opdracht}

Jaarlijks wordt postmortaal onderzoek verricht naar ongeveer 50 verse gestrande bruinvissen. Het hoofddoel van het onderzoek is het vaststellen van de doodsoorzaken van de onderzochte bruinvissen. Hier rapporteren we ook de biologische gegevens van de bruinvissen (geslacht en leeftijdsklasse) en hun fysieke condities; beide in relatie tot de doodsoorzaak.

Daarnaast worden van de onderzochte bruinvissen weefsels verzameld waarmee aanvullende onderzoeken kunnen worden uitgevoerd. Hierbij gaat het bijvoorbeeld om de maag voor dieetonderzoek en huid, lever, nier en spier voor contaminanten onderzoek (beide onderzoeken worden uitgevoerd in samenwerking met WMR). Ingevroren stukjes weefsel van (verse) bruinvissen worden in een weefselbank opgeslagen. Weefsels zijn in overleg beschikbaar voor aanvullende onderzoeken, zowel nationaal als internationaal. 

Bij een melding van een levende bruinvis die op het strand komt te overlijden, of van een verse dood gevonden bruinvis, neemt het vrijwillige strandingsnetwerk contact op met de UU. Transport van het karkas werd binnen 24 uur na melding gerealiseerd, zodat de autopsie zo snel als praktisch en logistiek mogelijk kon plaatsvinden. De autopsies werden uitgevoerd volgens eerder beschreven protocollen en methoden (Kuiken \& García-Hartmann 1993; Begeman et al. 2014), welke in 2019 zijn herzien en herschreven in opdracht van ASCOBANS en ACCOBAMS (zie: IJsseldijk et al. 2019). Ze bestaan uit een uitgebreid uitwendig en een inwendig onderzoek om de meest waarschijnlijke doodsoorzaak/oorzaken van ieder individu te achterhalen. Tijdens de autopsies werden monsters genomen en gefixeerd voor histologisch onderzoek. Tevens werden monsters voor onder andere bacteriologisch en virologisch onderzoek verzameld om aanvullend onderzoek naar pathogenen uit te voeren.

\subsection{Macroscopisch onderzoek}

Bruinvissen werden bij aankomst op de UU gewogen en gemeten en het geslacht werd bepaald. Dieren werden ingedeeld in drie leeftijdsklassen op basis van hun totale lengte: neonaat $<90 \mathrm{~cm}$, juveniel $90-130 \mathrm{~cm}$ of volwassen $>130 \mathrm{~cm}$, waarbij de geslachtsorganen van dieren rond de $130 \mathrm{~cm}$ werden gecheckt om de uiteindelijke differentiatie tussen juveniel en adult te maken.

Strandingsgegevens, bestaande uit de locatie en datum, werden genoteerd. Ieder dier werd volledig gefotografeerd. Daarbij werd voor ieder dier gecontroleerd of er uitwendige tekenen waren van ziekte (bijvoorbeeld huidlaesies zoals beschreven in Van Beurden et al. 2015a,b), interactie met andere soorten (bijvoorbeeld bijtwonden van zeehonden of vossen, cq. Leopold et al. 2015 en IJsseldijk \& Geelhoed, 2016) of kenmerken wijzend op bijvangst (bijvoorbeeld door de aanwezigheid van netafdrukken; Bernaldo de Quirós et al. 2018; IJsseldijk et al. in review). Dit werd beschreven en fotografisch vastgelegd, en waar nodig bemonsterd.

Bij ieder dier werd de staat van ontbinding bepaald. De staat van ontbinding is in vijf categorieën onderverdeeld (Decomposition Condition Code, DCC) met 1 (heel vers) tot en met 5 (in verregaande staat van ontbinding). Ook werd de voedingstoestand bepaald. De voedingstoestand is af te leiden van de blubberdikte en spiermassa, gezamenlijk met de aanwezigheid van inwendig vet. Naar aanleiding van deze metingen en observaties is er een Nutritional Condition Code (NCC) per bruinvis genoteerd, met 1 (zeer goed) tot en met 6 (zeer slecht).

Tijdens het inwendige onderzoek werden alle aanwezige organen bekeken, beoordeeld, beschreven en bemonsterd.

\subsection{Histologisch onderzoek}

Tijdens de autopsie werden monsters voor histologisch onderzoek verzameld en gefixeerd. De standaard bemonsterde weefsels (indien aanwezig) zijn: huid, rugspier, hersenen, trachea, thymus, schildklier, longen en bijbehorende lymfeknoop, hart, magen, milt, pancreas, lever, bijnieren, nieren, darm en bijbehorende lymfeknoop, urineblaas, melkklier, geslachtsorgaan en bijbehorende lymfeknoop, en in geval van dracht placenta, navelstreng en organen van de foetus (voor zover mogelijk). Laesies werden extra bemonsterd.

In formaline gefixeerd materiaal werd volgens standaardprocedure in paraffine ingebed en gesneden, waarna de coupes werden gekleurd met hematoxyline en eosine (H\&E). Een veterinair patholoog beoordeelde de coupes om eventuele afwijkingen op celniveau vast te stellen. Om verdere afwijkingen 
vast te stellen behoren extra kleuringen (immuunhistochemie), ontkalking van benig materiaal en de beoordeling hiervan tot het histologisch onderzoek.

\subsection{Aanvullend onderzoek}

Wanneer er aan de hand van het histologisch of cytologisch onderzoek een verdenking van een infectie op bacteriologische, virologische of mycotische basis was, werd per casus beoordeeld of aanvullend onderzoek noodzakelijk en mogelijk was om het etiologische agens verder te typeren. Wanneer infecties geassocieerde pathologie hebben welke direct gerelateerd waren aan de doodsoorzaak, is aanvullend onderzoek ingesteld. In de volgende paragrafen volgt een beschrijving van het microbiologisch onderzoek welke is uitgevoerd bij gestrande bruinvissen in 2019. Een overzicht van de uitgevoerde testen is te vinden in Tabel 3.1. Daarnaast werd tijdens de autopsie de mate van parasitaire infectie gedocumenteerd, alsmede de ernst van deze infectie(s).

\section{Bacteriologie}

Voor bacteriologisch onderzoek werd het verzamelde materiaal op twee bloedagarplaten en één MacConkey agarplaat gesmeerd. Eén bloedagarplaat werd anaeroob bebroed $\left(2 \times 24 \mathrm{~h} \mathrm{bij} 37^{\circ} \mathrm{C}\right)$, de andere bloedagarplaat en MacConkey agarplaat werden aeroob bebroed $\left(2 \times 24 \mathrm{~h}\right.$ bij $\left.37^{\circ} \mathrm{C}\right)$. Bij hersenen longweefsel werd daarnaast een extra plaat ingezet (zgn. chocoladeplaat); deze werd microäerofiel $2 \times 48 \mathrm{~h}$ bij $37^{\circ} \mathrm{C}$ bebroed. Voor het onderzoek naar de darminhoud werd ook een zogenoemde BGAplaat ingezet om de aan- of afwezigheid van Salmonella te onderzoeken. Alle platen werden dagelijks beoordeeld op bacteriegroei door een microbioloog. Verdachte kolonies werden geïdentificeerd met behulp van MALDI-TOF. Bacteriologisch onderzoek werd uitgevoerd bij het Veterinair Microbiologisch Diagnostisch Centrum van de Faculteit Diergeneeskunde (VMDC).

Daarnaast werd aandacht besteed aan het identificeren van bacteriële zoönosen. Brucellose is een bacteriële infectie welke steeds vaker wordt gevonden in zeezoogdieren. Sommige Brucella spp. zijn onder andere in staat om zoönotische infecties bij mensen te veroorzaken en abortus in vee te induceren. Brucella ceti in bruinvissen is eerder geïsoleerd uit verschillende organen, waaronder long, verschillende lymfeknopen en geslachtsorganen, maar ook uit longwormen verzameld uit de luchtwegen van bruinvissen (o.a. Dagleish et al. 2008; Maio et al. 2014; IJsseldijk et al. 2017). In een studie naar het voorkomen van Brucella spp. infecties in bruinvissen gestrand in Nederland tussen 2008-2011 werd een prevalentie van 6.3\% vastgesteld (Maio et al. 2014). Naast brucellose zijn er echter nog tal van andere bacteriële infecties bekend bij bruinvissen welke een zoönotisch potentieel hebben. Voorbeelden hiervan zijn: salmonellose (Foster et al. 1999; Davison et al. 2010) en infecties met Neisseria animaloris (Foster et al. 2019). Door de potentieel zoönotische aard van deze infecties en het contact tussen (levend) gestrande bruinvissen en strandgangers, evenals vrijwilligers van het strandingsnetwerk, werd bij verdenking van dergelijke infecties extra onderzoek ingesteld.

\section{Mycologie}

Voor mycologisch onderzoek werd het verzamelde materiaal op een Sabouraud Agar en een Maltagarplaat gesmeerd. Deze werden maximaal tien dagen bebroed bij $30^{\circ} \mathrm{C}$. De platen werden om de dag beoordeeld op schimmelgroei door een microbioloog. Verdachte kolonies werden geïdentificeerd op basis van fenotypische kenmerken en microscopisch onderzoek. Mycologisch onderzoek werd tevens uitgevoerd bij het VMDC. 
Tabel 3.1 Aanvullende testen na histologisch onderzoek.

\begin{tabular}{|c|c|c|}
\hline Onderzoek & Organen & Aantal dieren \\
\hline \multirow[t]{15}{*}{ Bacteriologisch } & Long & 22 \\
\hline & Lever & 9 \\
\hline & Huid & 4 \\
\hline & Meloen & 1 \\
\hline & Maag & 2 \\
\hline & Brein & 1 \\
\hline & Darm & 6 \\
\hline & Nier & 1 \\
\hline & Ruggenmerg & 1 \\
\hline & Lymfeknoop & 4 \\
\hline & Placenta & 1 \\
\hline & Baarmoeder & 2 \\
\hline & Buikvlies & 1 \\
\hline & Onderhuids abces & 3 \\
\hline & Borstvin & 1 \\
\hline \multirow[t]{3}{*}{ Mycologisch } & Long & 4 \\
\hline & Brein & 1 \\
\hline & Lymfeknoop & 1 \\
\hline
\end{tabular}

\section{Parasitologie}

Parasieten zijn veel voorkomend in bruinvissen, vooral naarmate dieren ouder worden, met een zeer hoge prevalentie in volwassen dieren (Ten Doeschate et al. 2017). Het voorkomen van parasieten in longen, lever, magen en oren werd standaard gedocumenteerd op semi-kwantitatieve schaal: geen, mild, middelmatig en ernstig. De aan- of afwezigheid van externe parasieten op de huid, of in huidplooien (o.a. wonden en genitale opening) en in de darm werd tevens standaard gedocumenteerd. De beoordeling van de geassocieerde pathologie in de longen, de lever en de magen is onderdeel van het histologisch onderzoek.

\subsection{Doodsoorzaak categorieën}

De combinatie van alle uitwendige en inwendige bevindingen, resultaten van het histopathologisch onderzoek en het eventueel uitgevoerde aanvullend onderzoek resulteert per casus in een conclusie en het vaststellen van een waarschijnlijke doodsoorzaakcategorie. Daarnaast worden hier relevante additionele bevindingen gerapporteerd. Om een vergelijking met voorgaande jaren te kunnen maken werd gebruik gemaakt van verschillende categorieën, gebaseerd op de opgedane kennis in voorgaande jaren: bijvangst, slachtoffer door aanval van grijze zeehond, infectieziekten, verhongering, vermagering, perinataal, overig (waaronder dystocia en trauma) en onduidelijk. De volledige omschrijving van deze categorieën staat in Bijlage 1. 



\section{Resultaten}

\subsection{Herkomst en biologische gegevens}

Uit alle kustprovincies van Nederland zijn bruinvissen ontvangen, met de meeste dieren uit ZuidHolland $(n=19)$, Noord-Holland $(n=16)$ en de Delta $(n=14)$. Van de Waddeneilanden zijn acht bruinvissen onderzocht (waarvan één van Texel, twee van Vlieland, drie van Terschelling en twee van Ameland). Van het vasteland van Friesland en Groningen, en van Schiermonnikoog kwamen geen dieren (Figuur 4.1, Bijlage 2). De meeste van de onderzochte bruinvissen strandden in juli $(n=11)$ gevolgd door januari $(n=10)$ en maart $(n=9)$. Minder gestrande bruinvissen uit de maanden februari $(n=5)$, april en mei (beide $n=4)$, juni, september, oktober en december $(n=3$ per maand) en augustus $(n=2)$ werden onderzocht. Uit één maand, namelijk november, werden geen gestrande bruinvissen verzameld voor onderzoek (zie ook discussie met betrekking tot aantal strandingen per maand).

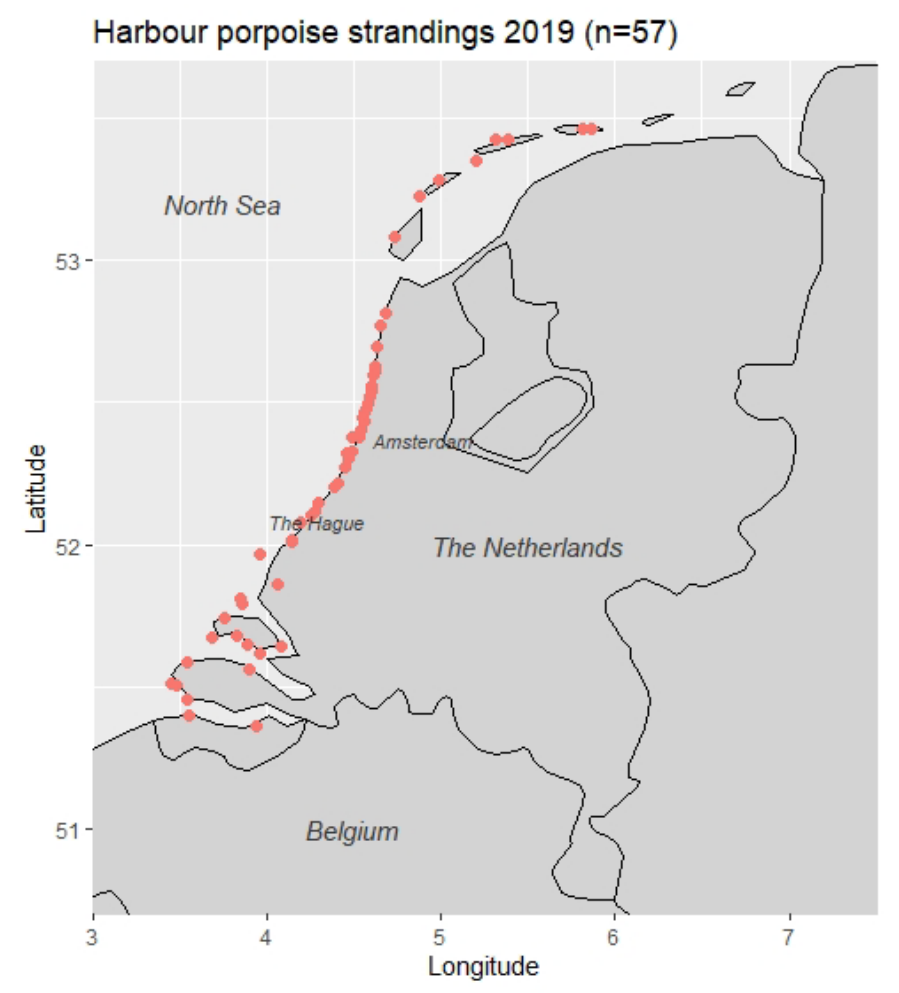

Figuur 4.1 Herkomst onderzochte bruinvissen $2019(n=57)$.

Het grootste deel van de onderzochte dieren werd niet ingevroren voorafgaand aan de autopsie (88\%). De meeste bruinvissen waren zeer vers (DCC1, 16\%) of vers (DCC2, 61\%) ten tijde van de sectie. De overige (22\%) waren minder verse dieren, waarbij histopathologie dan ook beperkt mogelijk was. De lichaamsconditie (NCC) varieerde van NCC1-NCC6 en hing vaak samen met de doodsoorzaken van dieren (Bijlage 2).

In totaal zijn 22 volwassen bruinvissen onderzocht, 24 juveniele dieren en 11 neonaten. De verdeling naar geslacht was 31 man en 26 vrouw. De verdeling man/vrouw binnen de verschillende leeftijdsklasse is niet geheel gelijk: er zijn meer mannelijke juveniele dieren gevonden en meer vrouwelijke adulte (Figuur 4.2 \& 4.3). Daarnaast werden zes foetussen gevonden; twee vrouwtjes en vier mannetjes.

De neonaten $(n=11)$ werden voornamelijk in mei-juli gevonden $(n=10)$ en één op 2 september. Deze pasgeboren dieren waren gemiddeld $80.8 \mathrm{~cm}$ lang en gemiddeld $12 \mathrm{~kg}$ zwaar. Juveniele en volwassen dieren werden gedurende het hele jaar gevonden. Juveniele dieren $(n=24)$ hadden een gemiddelde 
totale lengte van $106 \mathrm{~cm}$. De maximale totale lengte in de groep juvenielen was een vrouwelijk dier van $131.5 \mathrm{~cm}$. Volwassen vrouwtjes $(n=15)$ waren gemiddeld $153.2 \mathrm{~cm}$ lang en mannelijke dieren $(n=7)$ waren kleiner, met $141 \mathrm{~cm}$. De foetussen $(n=6)$ werden gevonden in de maanden januari $(n=2)$, maart $(n=1)$, mei $(n=2)$ en september $(n=1)$, met lengtes tussen de 8.7 en $76.5 \mathrm{~cm}$.

\section{Leeftijds- en geslachtsverdeling}
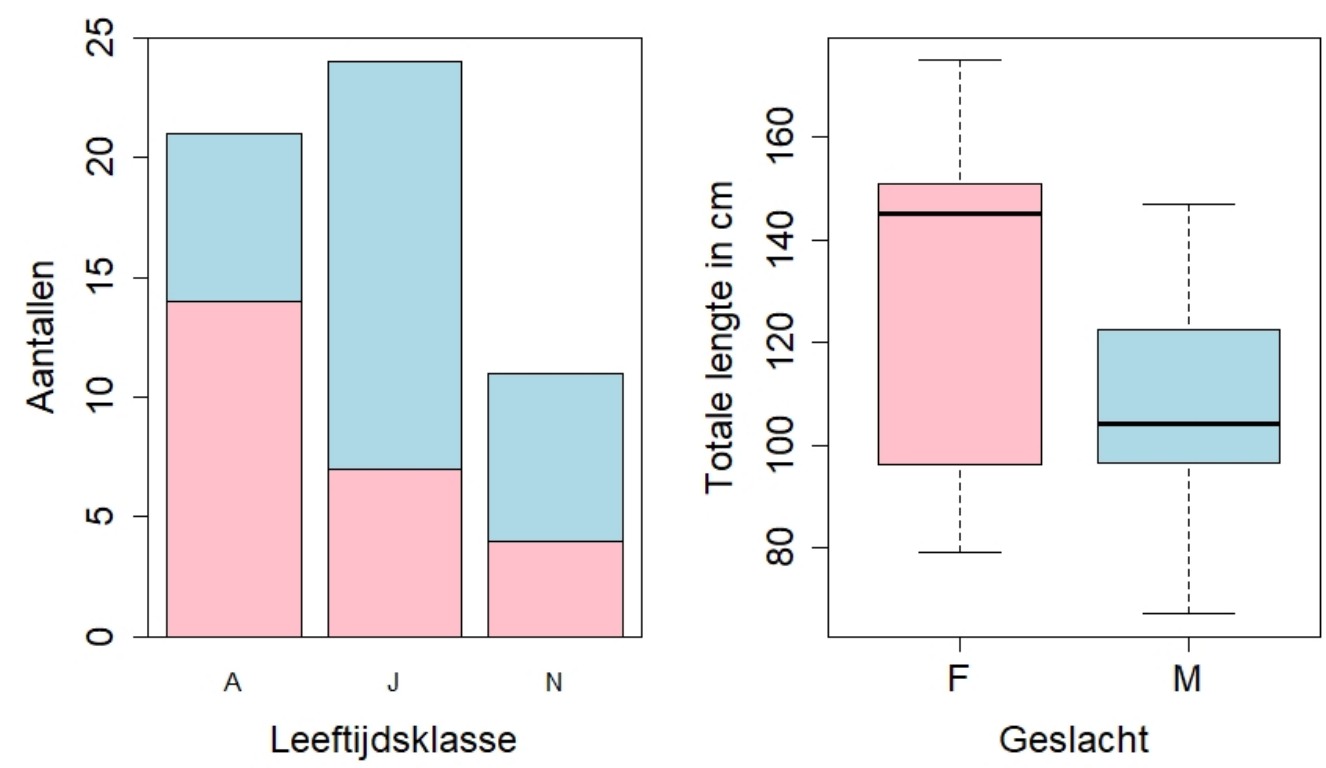

Figuur 4.2 Leeftijds- en geslachtsverdeling (links) en lengte per geslacht (rechts). A=volwassen, $J=j u v e n i e l, N=n e o n a a t, F=v r o u w e l i j k, M=m a n n e l i j k$. De roze kolommen zijn de vrouwelijke dieren; de blauwe kolommen zijn de mannelijke dieren. Kolomdikte van de boxplot representeert de monstergrootte.

\subsection{Doodsoorzaken}

Postmortaal onderzoek in 2019 van 57 casussen heeft uitgewezen dat de meeste van de onderzochte dieren gestorven waren door een infectieziekte (30\%). Grijze zeehond aanvallen waren de directe of indirecte doodsoorzaak van $21 \%$ van de onderzochte bruinvissen in 2019 en bijvangst bij 11\% (Figuur 4.3).

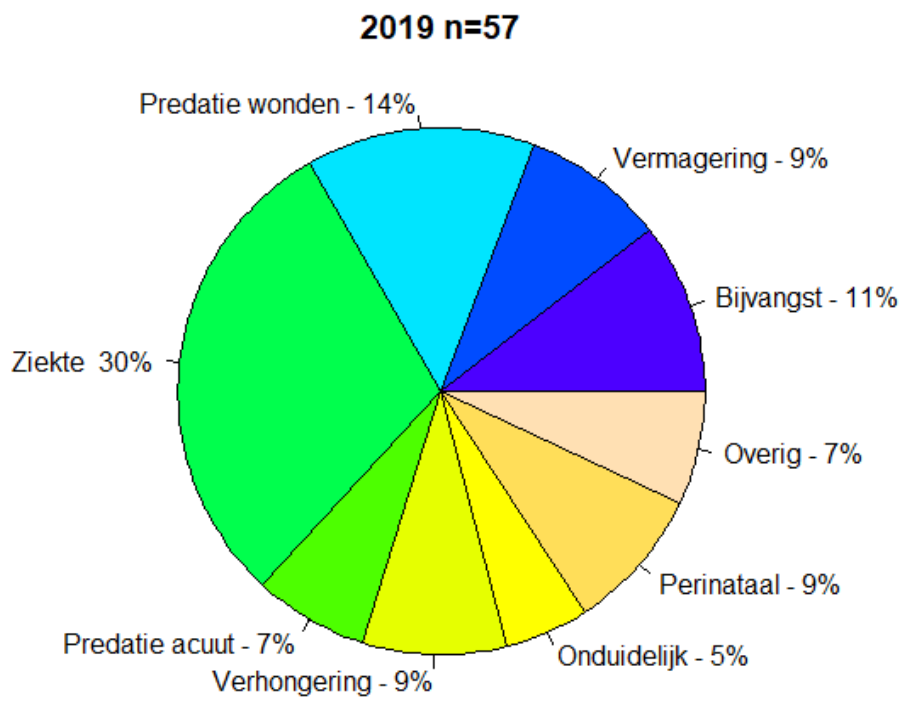

Figuur 4.3 Overzicht van doodsoorzaak categorieën van de in 2019 onderzochte bruinvissen $(n=57)$ 


\subsubsection{Infectieziekten}

Zeventien bruinvissen (30\%) vielen in de doodsoorzaak categorie infectieziekten (UT1718, UT1726, UT1727, UT1728, UT1730, UT1734, UT1735, UT1739, UT1740, UT1745, UT1752, UT1761, UT1767, UT1775, UT1776, UT1781 en UT1783). Dit waren tien volwassen dieren (45\% van alle onderzochte volwassen bruinvissen) en zeven juveniele dieren (29\% van alle onderzochte juveniele bruinvissen). Vier bruinvissen in deze categorie waren levend op het strand gevonden (UT1735, UT1740, UT1752 en UT1783). Elf bruinvissen in deze doodsoorzaakcategorie hadden middelmatige tot (zeer) ernstige ontstekingen in drie of meer organen (UT1726, UT1727, UT1728, UT1730, UT1734, UT1745, UT1752, UT1761, UT1767, UT1775 en UT1783).

De meest voorkomende diagnose in deze categorie was een longontsteking: bij zestien bruinvissen werd dit gerelateerd aan de strandings/doodsoorzaak (alle behalve UT1739), waarbij in vijftien casussen parasieten in de longen aanwezig waren (alle behalve UT1730). Eén bruinvis had een mycotische bronchitis (UT1730). Bij de vijftien bruinvissen met parasieten in de longen waren longontstekingen bij zes vermoedelijk volledig door de parasieten geïnduceerd, terwijl bij de andere negen bruinvissen ook een bacteriële infectie in de longen aanwezig was.

Vijftien bruinvissen hadden huidontstekingen (UT1718, UT1726, UT1727, UT1730, UT1734, UT1735, UT1739, UT1745, UT1752, UT1761, UT1767, UT1775, UT1776, UT1781, UT1783). De etiologie was vermoedelijk viraal bij alle behalve UT1730; een dier met een ernstige, ontstoken grote wond in het 'nek' gebied (Figuur 4.4). De oorzaak van de huid- en spierontsteking bij dit dier was vermoedelijk ernstig en scherp trauma, omdat in de onderliggende rugwervels van de wond ook kleine fracturen in de dorsale spinale uitsteeksels van de wervels (spinous processes) aanwezig waren. Echter gezien het pathologisch beeld en onderliggend ziektebeeld van dit dier heeft deze bruinvis hier vermoedelijk enige tijd mee rondgezwommen. Daarnaast hadden twee bruinvissen (UT1761 en UT1783) bilaterale littekens op het staartstuk, passend bij een oudere grijze zeehond aanval. Echter deze wonden waren geheeld en daardoor vermoedelijk niet direct gerelateerd aan de stranding- of doodsoorzaak.

Andere ontstekingen werden gevonden in de levers van tien bruinvissen (UT1726, UT1728, UT1740, UT1745, UT1761, UT1767, UT1775, UT1776, UT1783). Bij zes van deze bruinvissen werden ook macroscopisch trematoden infecties (leverbot) gevonden. De leverontstekingen waren van (gedeeltelijk) bacteriële aard bij twee bruinvissen (UT1726 en UT1730), en bij één bruinvis kon de etiologie niet worden vastgesteld (UT1740). Vier bruinvissen hadden ontstekingen in het spijsverteringskanaal (mondholte, slokdarm en/of magen; UT1726, UT1734, UT1752 en UT1776). Vijf bruinvissen hadden ontstekingsinfiltraten in het centrale zenuwstelsel (UT1718, UT1726, UT1727, UT1752, UT1775), waarbij het bij drie bruinvissen ging om een hersenontsteking die zich kenmerkte door perivasculaire cuffing (UT1718, UT1727 en UT1752), één bruinvis had een hersenvliesontsteking (UT1726) en bij één andere bruinvis werden verspreid in de grote hersenen enkele macrofagen gezien (UT1755). Twee bruinvissen hadden afwijkingen aan de nieren; een vermoedelijke lokale parasitaire infectie (neospora, UT1745) en een ontsteking in de nierfilters (UT1783). Eén bruinvis had een chronische ontsteking aan het hart en daarnaast ook ontstekingen in de sereuze membranen, waaronder het buikvlies (UT1728). Een ontsteking van het baarmoederslijmvlies (endometritis) en bacteriële ontsteking in het mesenterium werden gevonden bij één volwassen vrouwtje (UT1761). Eén andere bruinvis had een darmdraaiing als gevolg van ontstekingen aan het buikvlies (UT1727). Eén bruinvis had een acute darmontsteking met bloederige diarree (hemorragische enteritis; UT1775) van onbekende etiologie. 


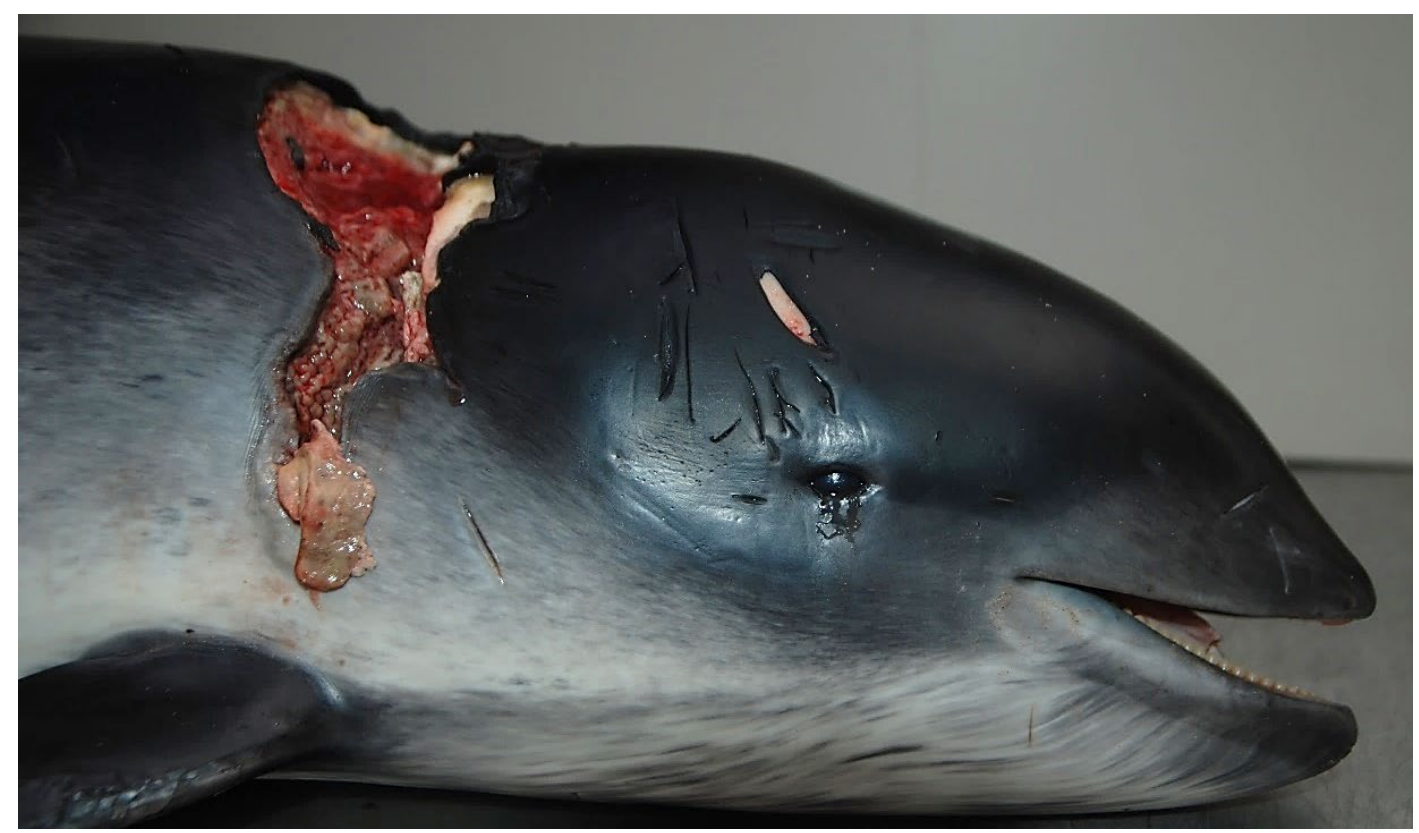

Figuur 4.4 UT1730. Ernstige open, ontstoken wond in 'nek' gebied, welke zich kenmerkte door bacterie-ophoping in de huid en het onderliggende spierweefsel. De oorsprong van deze wond was vermoedelijk scherp trauma, echter gezien de pathologische veranderingen en het ziektebeeld van deze bruinvis (zie tekst) heeft het dier hier vermoedelijk enige tijd mee rondgezwommen.

\subsubsection{Bijvangst}

Zes bruinvissen (11\%) vielen in de categorie bijvangst, met onderverdeling in de subklassen: hoogstwaarschijnlijk bijvangst ( $n=3$; UT1747, UT1750 en UT1779), waarschijnlijk bijvangst $(n=2$, UT1748 en UT1782) en zeker bijvangst ( $n=1$, UT1755). Dit waren vier juveniele dieren en twee volwassenen, waaronder twee mannen en vier vrouwen. Dieren werden gevonden in de maanden maart $(n=2)$, april, mei, oktober en december (alle $n=1$ ).

Bijvangst was bij één bruinvis (UT1755) met zekerheid de doodsoorzaak; dit dier werd aangetroffen in een staand want net dat vlak onder de kust bij Noordwijk stond. Strandrecreanten zagen het dier het visnet inzwemmen. Helaas konden zij de bruinvis niet op tijd naar de oppervlakte krijgen en is de bruinvis onder water gestikt. Met behulp van lokale medewerkers van het strandingsnetwerk is deze bruinvis verzameld voor postmortaal onderzoek. Ondanks de acute doodsoorzaak, ging het niet om een gezond dier. De voedingstoestand was matig en extern was een ernstige, chronische afwijking aan de kaak zichtbaar (Figuur 4.5A). Vermoedelijk heeft dit nog jonge dier enkele weken tot maanden eerder zijn kaak gebroken, waarbij de rechterkant van de onderkaak het omliggende weefsel perforeerde en een open breuk is ontstaan, wat resulteerde in een huid-, tandvlees- en botontsteking. Echter heeft deze ernstige afwijking het dier niet weerhouden van het vinden en vangen van voedsel. Op het oog was de maag vol met een deels onverteerde prooi ${ }^{1}$, wat het waarschijnlijk maakt dat deze bruinvis aan het jagen was vlak voor hij het visnet in zwom. Netafdrukken en inkepingen waren zeer duidelijk zichtbaar, onder andere rond de kop (Figuur 4.5A), de borstvinnen en staartvin. Daarnaast had deze bruinvis littekens op beide zijden van het staartstuk en de staartvin, wat morfologisch past bij een eerder door een grijze zeehond-geïnduceerd trauma (Figuur 4.5B). Het is goed mogelijk dat dit gerelateerd is aan de open kaakbreuk, maar andere oorzaken voor een dergelijk trauma (zoals een aanvaring met een object) kunnen niet worden uitgesloten, omdat het tijdspad onbekend is en de bruinvis dus ook na de kaakbreuk kan zijn aangevallen door een grijze zeehond. 

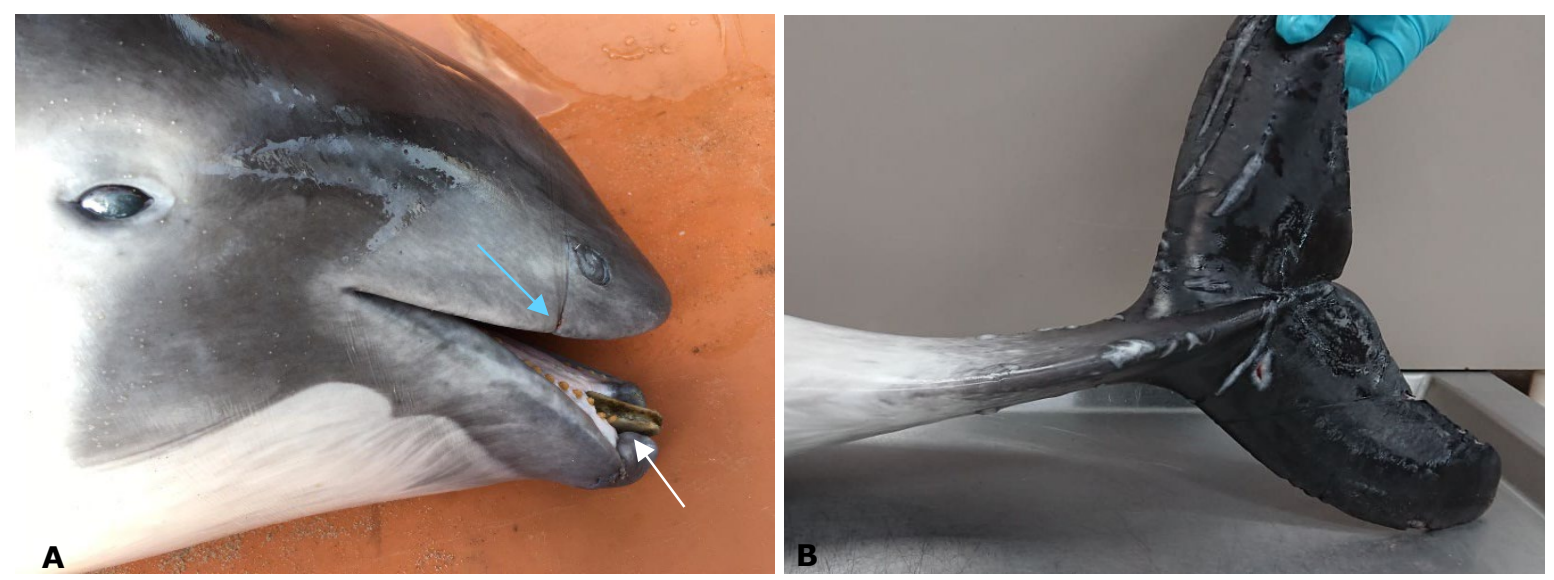

Figuur 4.5 UT1755. (A) Open kaakbreuk (aangegeven met de witte pijl) en duidelijke inkepingen van een visnet rond de bovenkaak en het rostrum (aangegeven met blauwe pijl) (Foto: Stichting SOS Dolfijn). (B) Littekens op de staartvin die vermoedelijk een gevolg zijn van een eerder trauma door een grijze zeehond aanval.

Bij de drie bruinvissen in de categorie 'hoogstwaarschijnlijk bijvangst' werden duidelijke en overtuigende externe kenmerken van bijvangst waargenomen. In de magen van deze dieren zat inhoud $^{1}$, o.a. (deels) onverteerde vis en andere prooi soorten (UT1747, UT1750, UT1779). Eén bruinvis was een adulte vrouw in matige voedingstoestand, met geringe (deels parasitaire) infecties in de longen en lever, en een minimale huidontsteking (UT1747). De andere twee bruinvissen waren juveniel, één dier had een geringe parasitaire longontsteking en geringe huidontsteking (UT1750, Figuur 4.6), het andere dier had een zeer acute longontsteking als gevolg van aspiratie van voedseldeeltjes, vermoedelijk ten tijde van de dood (UT1779). Geen van deze dieren toonde andere afwijkingen die de dood kon verklaren, en gezien de netafdrukken en inkepingen is bijvangst dus hoogstwaarschijnlijk de doodsoorzaak.

Eén bruinvis uit de categorie 'waarschijnlijk bijvangst' had mogelijk netinkepingen, maar was beschadigd door aaseters wat de interpretatie van de externe kenmerken bemoeilijkte (UT1782). Deze bruinvis was zwanger, in goede voedingstoestand en had recent gegeten, wat zichtbaar was aan een op het oog volle maag met deels nog onverteerde prooiresten ${ }^{1}$. Het dier had een ontsteking aan de maag waarvan de oorsprong niet kon worden achterhaald en een parasitaire longontsteking met mineralisaties. Echter zijn deze twee afwijkingen niet zodanig ernstig dat ze de dood van dit dier kunnen verklaren en gezien de goede voedingstoestand, de volle maag en geen aanwijzingen voor intraspecifiek of stomp trauma, lijkt bijvangst het meest waarschijnlijk. De andere bruinvis uit deze categorie (UT1748) was een juveniel vrouwtje in slechte voedingstoestand, met tekenen van een parasitaire longontsteking, waarbij grote hoeveelheden parasieten werden aangetroffen. Het dier had op het oog geen voedsel in de maag. Inkepingen waren zichtbaar op de staartvin, linker borstvin en het staartstuk. De doodsoorzaak was daarom waarschijnlijk bijvangst, echter ging het hier niet om een gezond dier. Het is niet mogelijk om met zekerheid te zeggen in hoeverre de afwijkingen mogelijk indirect hebben bijgedragen aan de doodsoorzaak.

\footnotetext{
${ }^{1}$ Gerapporteerde bevindingen zijn op basis van observaties tijdens de autopsies. Uitgebreid dieetonderzoek wordt uitgevoerd door Dr. M.F. Leopold (Wageningen Marine Research) en elders gerapporteerd.
} 


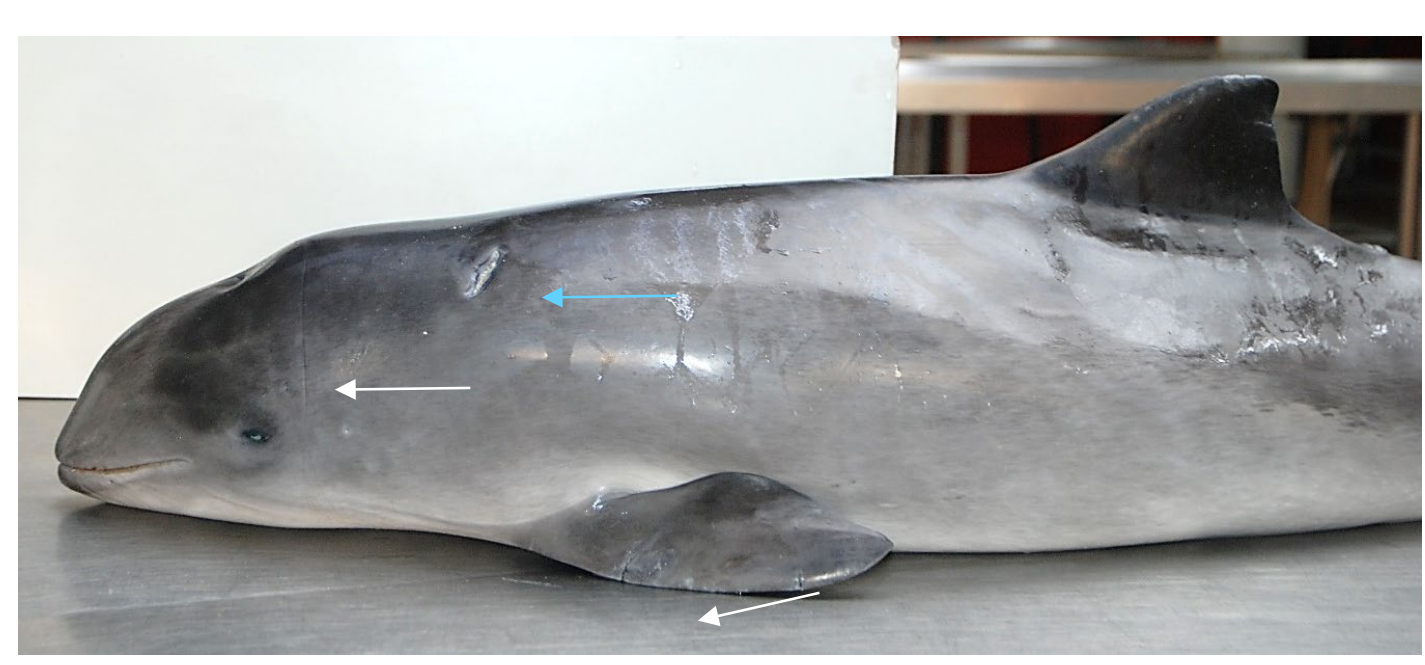

Figuur 4.6 UT1750. Gestrande bruinvis die hoogstwaarschijnlijk overleed na verstrikt te zijn geraakt in een net. Duidelijke imprint van een lijn is zichtbaar rond de kop en de borstvin (witte pijlen). Daarnaast had het dier een chronische ontsteking in de huid (blauwe pijl), maar dit was niet direct gerelateerd aan de doodsoorzaak.

\subsubsection{Grijze zeehond aanval}

Twaalf bruinvissen (21\%) vielen in de categorie grijze zeehond aanval. Deze categorie kan worden opgesplitst in twee groepen: bruinvissen die acuut overlijden door een grijze zeehond aanval en bruinvissen welke later als gevolg van bijtwonden stierven (zogenoemde 'chronisch'). De acute gevallen tonen grote mutilaties met bijtwonden. In 2019 kwamen de externe wonden bij vier dieren overeen met wonden die veroorzaakt worden door een grijze zeehond in een predatie aanval (UT1719, UT1764, UT1772, UT1780 en zie ook Leopold et al. 2015). Dieren waren in zeer goede tot middelmatige voedingstoestand (NCC1-3) en werden in januari, maart, juli en oktober gevonden. Het waren alle vier juveniele mannetjes. Andere significante afwijkingen, zoals tekenen van ziekte, werden in deze vier bruinvissen niet gevonden.

Acht andere bruinvissen stierven als gevolg van bijtwonden (UT1736, UT1737, UT1738, UT1741, UT1742, UT1744, UT1746 en UT1751). Deze dieren overleden door infectie van de bijtwond of door vermagering (zie Bijlage 1, beschrijving in Leopold et al. 2015 en Foster et al. 2019). Dit waren drie volwassen dieren en vijf juveniele bruinvissen, waarvan vijf mannelijk en drie vrouwelijk. Alle dieren hadden ernstige huidontstekingen (Figuur 4.7). Daarnaast werd een ernstige longontsteking in zes dieren gediagnosticeerd (UT1737, UT1738, UT1741, UT1742, UT1744, UT1746), waarvan één bruinvis een additionele ernstige longvliesontsteking en klaplong had (UT1741). Eén bruinvis had ontstekingen in het ruggenmerg (UT1736), twee in het bot onderliggend aan de bijtwonden (UT1737 en UT1744), één bruinvis had naast een longontsteking ook een ernstige ontsteking in de lever (UT1738) en drie bruinvissen (UT1737, UT1742, UT1744) hadden een verspreide bacteriële infectie, met ontstekingen en abcessen in de lymfeknopen alsmede in meerdere organen. Eén bruinvis was levend gestrand (UT1746), maar overleed spoedig ter plaatse. 

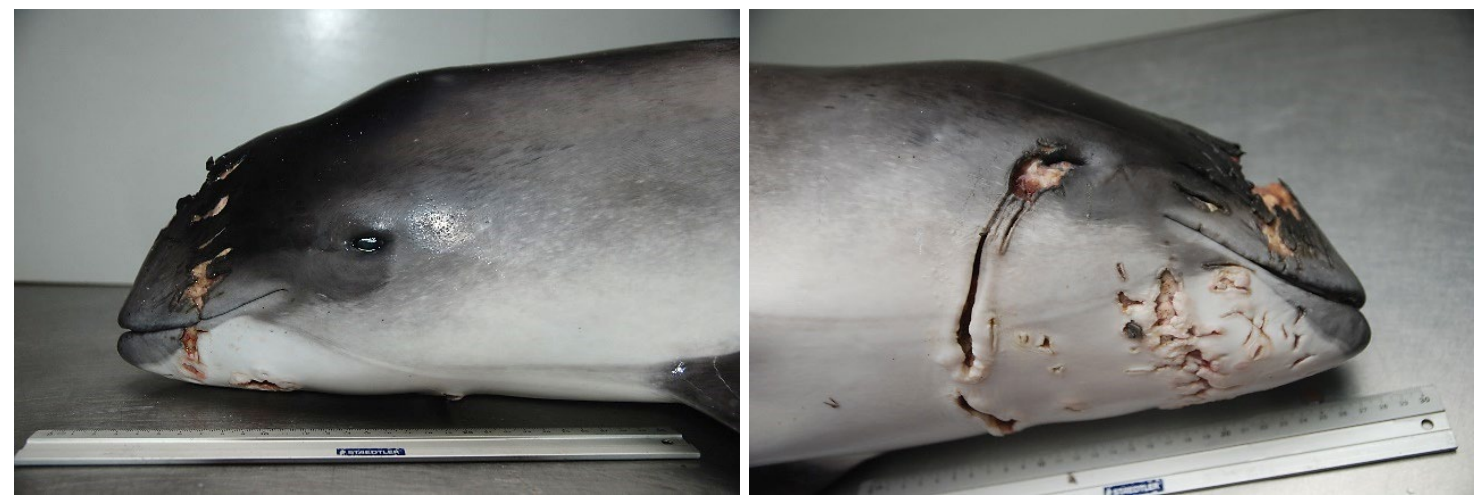

Figuur 4.7: UT1738. Bruinvis met chronische en ernstig ontstoken bijtwond op beide zijde van de kop en waarbij het rechteroog, de meloen (akoestisch orgaan op de kop) en huid met onderliggende weefsel ernstig beschadigd zijn.

\subsubsection{Peri- en neonatale sterfte}

Bij elf jonge bruinvissen die strandden in de zomer waren geen tekenen van infectieziekten of extern trauma (19\%). Deze dieren strandden van mei tot september, wat overeenkomt met het geboorteseizoen voor bruinvissen in de Noordzee (Lockyer 2003), met uitzondering van één bruinvis welke in september dood gevonden werd. Bevindingen waren over het algemeen overeenkomend tussen deze jonge dieren, met vervetting van de lever (hepatische lipidose) als indicatie voor acute verhongering het meest voorkomend $(n=9)$. Leververvetting was de enige significante bevinding bij drie bruinvissen (UT1765, UT1768 en UT1769). Bij twee andere neonaten, gestrand eind mei (UT1754) en begin juni (UT1757), waren er vermoedelijk problemen tijdens de geboorte. Beide hadden bloedingen in het centrale zenuwstelsel, wat mogelijk een gevolg kan zijn van enige tijd klem zitten tijdens de bevalling. Twee andere neonaten (UT1758 en UT1759) waren levend gestrand en geëuthanaseerd ${ }^{2}$, beide waren pasgeboren dieren (gestrand begin en eind juni), zonder tekenen van recente melk inname. Drie andere neonaten (UT1762, UT1763 en UT1766), alle drie dood gevonden in juli, waren ernstig vermagerd; een aanwijzing voor langere tijd onvoldoende voedselopname, wellicht ook al tijdens de zwangerschap. Eén bruinvis (UT1769) toonde extern tekenen van krassen die konden passen bij klauwafdrukken van een zeehond, maar ook strandings gerelateerd konden zijn (bijvoorbeeld door schelpen). Het ging om acute krassen die microscopisch weinig reactie toonde. Ook bij dit dier was er zeer uitgebreide leververvetting; indicatief voor verhongering.

\subsubsection{Vermagering}

Bij vier bruinvissen was de belangrijkste bevinding van het postmortaal onderzoek een zeer ernstige vermagering (7\%, UT1743, UT1749, UT1777, UT1778). Dit waren twee juveniele mannetjes en twee adulte vrouwtjes, die beide niet zwanger noch lacterend waren. Drie bruinvissen hadden ontstekingen in het spijsverteringskanaal: in de mondholte (UT1743), de slokdarm (UT1743 en UT1777) en maag (UT1749). Parasitaire longontstekingen werden gediagnosticeerd in drie dieren (UT1743, UT1777, UT1778). De gemiddelde blubberdiktes van deze vier dieren was $7.7 \mathrm{~mm}$ (range: 7.5 tot $10.7 \mathrm{~mm}$ ). Overigens zijn dit niet de enige vermagerde dieren in de groep onderzochte dieren van 2019, maar wel de enige zeer magere dieren waarbij aanwijzingen voor andere doodsoorzaken, zoals significante infectieziekten, intraspecifiek trauma of bijvangst niet gevonden werden.

\subsubsection{Overig}

Zeven dieren konden niet in bovenstaande categorieën worden ingedeeld. Bij twee bruinvissen (UT1770 en UT1771) werden aanwijzingen voor onderhuidse bloedingen gevonden, wat indicatief is voor stomp trauma. UT1770 had onderhuidse bloedingen rond de schouderbladen. De precieze aard van het trauma is moeilijk vast te stellen, echter had het dier enkele parallelle krassen welke mogelijk een gevolg van intraspecifieke interactie kan zijn geweest en een verklaring voor het trauma zou

\footnotetext{
${ }^{2}$ Euthanasie van gestrande bruinvissen wordt uitgevoerd door een dierenarts na consult bij Stichting SoS Dolfijn. De auteurs van deze rapportage hebben geen rol bij deze besluitvorming.
} 
kunnen zijn. Het was een zeer magere, jonge bruinvis zonder aanwijzingen dat het dier recent nog had gedronken of gegeten. De andere bruinvis (UT1771) was een volwassen vrouwtje, gestrand in augustus, die vermoedelijk net zwanger was gezien de macroscopische veranderingen in de uterus en ovaria (de eerste zes weken van een zwangerschap zijn moeilijk te herkennen, omdat een embryo nog niet als zodanig zichtbaar is). Het ging om een DCC3 dier ten tijde van de stranding, met een duidelijke grote hoofdwond (Figuur 4.8, overigens vergelijkbaar met de wond van UT1730; zie hierboven en discussie). Bijttrauma (grijze zeehond aanval) leek niet waarschijnlijk vanwege afwezigheid van de kenmerkende diepe 'puncture' wonden (Leopold et al. 2015). Vermoedelijk ging het hier om scherp trauma, bijvoorbeeld als gevolg van een aanvaring met een schroef of ander scherp object. Het dier heeft hier enige tijd mee rondgezwommen, want er was macroscopisch duidelijk reactie in het omliggende weefsel (teken van ontsteking), maar significante ontstekingen of andere afwijkingen aan de inwendige organen werden niet gevonden.

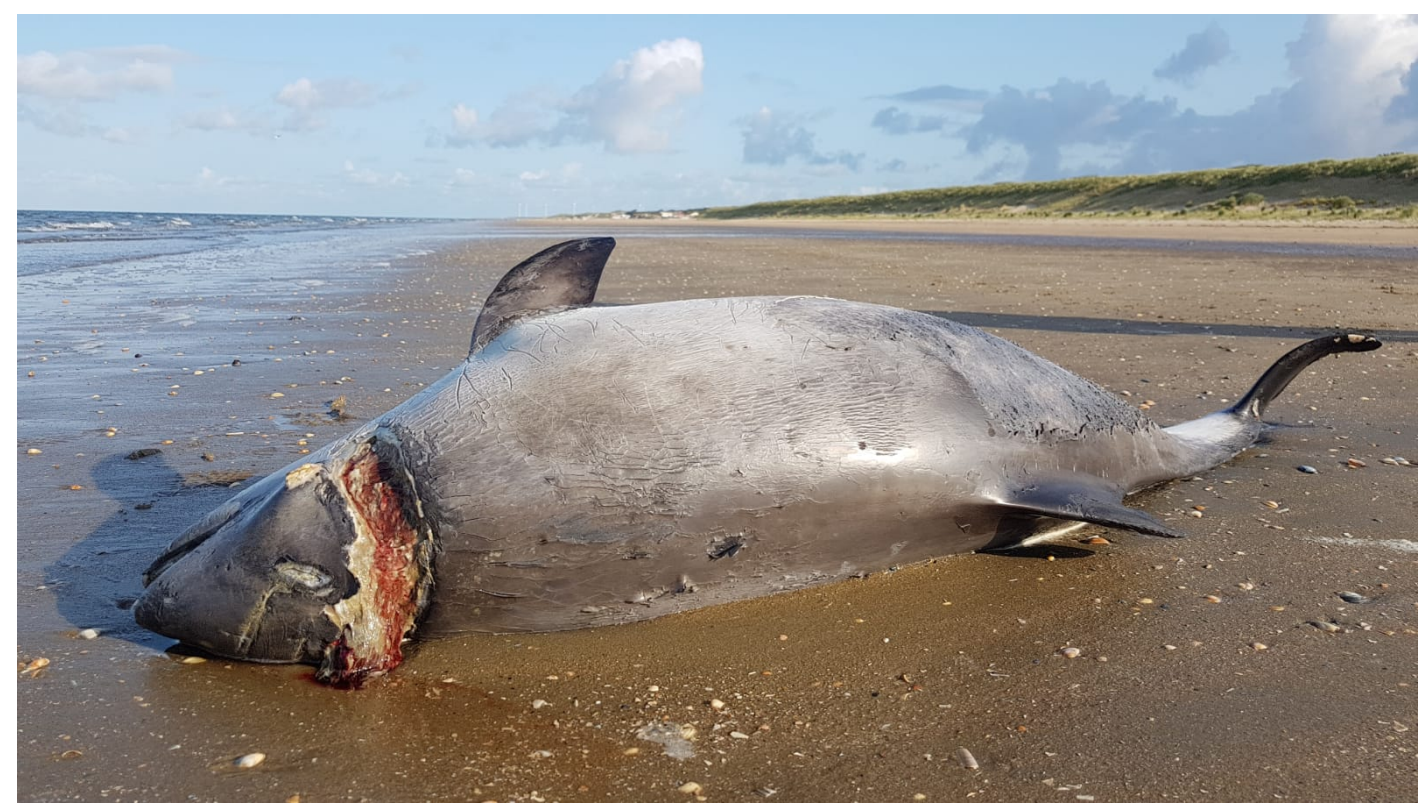

Figuur 4.8 UT1771. Volwassen bruinvis met scherpe hoofdwond. Foto: EHBZ Martin de Boer

Twee volwassen vrouwelijke en zwangere bruinvissen stierven tijdens of als gevolg van de bevalling (dystocia). Bij de ene bruinvis (UT1753) was het nog ongeboren jong gepositioneerd in de linker uterus hoorn. Deze foetus verkeerde in verdere staat van ontbinding dan moeder (DCC4 versus DCC2) en ontstekingen van de placenta, de baarmoeder, en als gevolg daarvan het buikvlies van de moeder hebben mogelijk geresulteerd in een septische shock. Gezien de verschillen in de versheid tussen moeder en foetus, is de foetus waarschijnlijk eerder overleden en in de baarmoeder gaan ontbinden, wat in dergelijke infecties resulteert. De andere volwassen vrouw (UT1756) was tevens in partu, maar hier lag de foetus met de rugvin in het geboortekanaal. De foetus lag klem en door de enorme druk resulteerde dat in een ruptuur van zowel de baarmoeder als de buikwand van de moeder (Figuur 4.9), waarbij de foetus vrij in de buikholte was komen te liggen. Gezien de ernst van de buikwond en het inwendige letsel is deze bruinvis overleden.

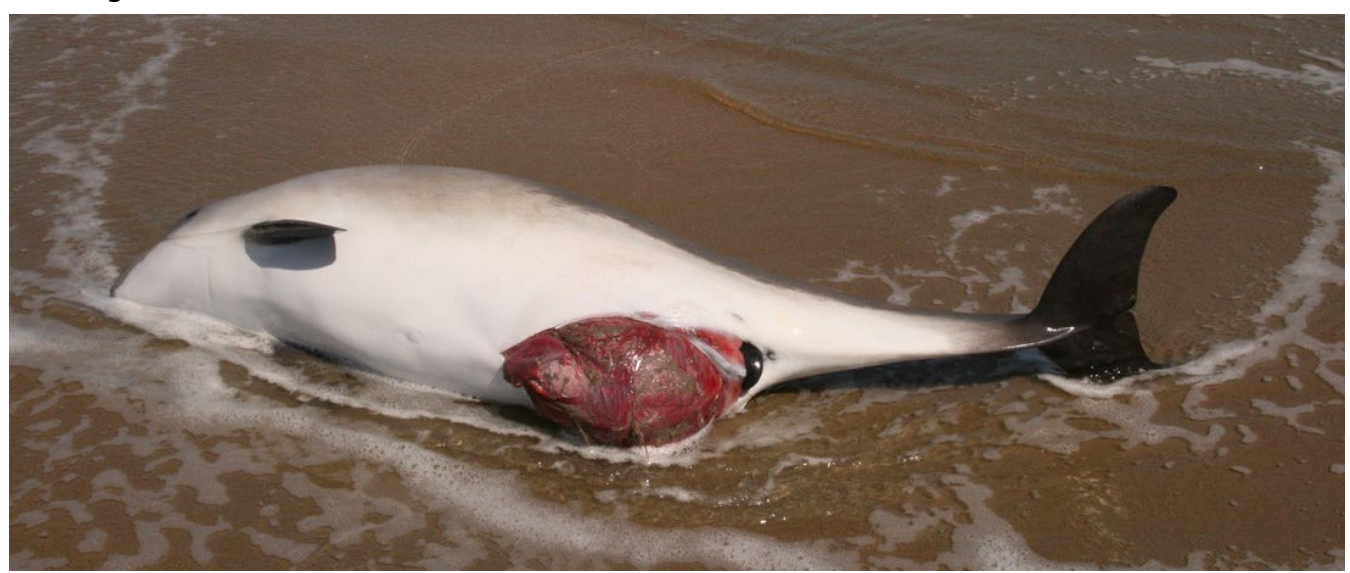

Figuur 4.9 UT1756. Buikwand ruptuur als gevolg van dystocia en nadat de foetus in 'stuit positie' (met de rugvin in het geboortekanaal) was klem komen te liggen. Foto: EHBZ Noodwijk, Kees \& Rinus. 
Eén bruinvis (UT1774) was geëuthanaseerd ${ }^{2}$ na levend stranden. Levend stranden is voor walvisachtigen veelal fataal, waarbij ze vrij snel spierschade oplopen doordat ze in het water de zwaartekracht niet gewend zijn waarmee ze te maken krijgen wanneer ze op het strand liggen (Herráez et al. 2013). Het ging om een jong juveniel dier (93 cm, gestrand in augustus). Er kon geen oorzaak voor het stranden worden gevonden.

De doodsoorzaak van twee bruinvissen (UT1729 en UT1760) bleef onduidelijk. Dit waren beide volwassen vrouwtjes. Eén bruinvis (UT1729) was vers (DCC2) maar wel ingevroren voortijdig aan de sectie. Het ging om een zwanger vrouwtje in goede voedingstoestand. Het dier had op het oog geen voedselresten in de maag. Er waren geen externe afwijkingen (geen tekenen van bijvangst, bijtwonden, huidontstekingen etc.), wel had het dier een longontsteking en milde hoeveelheden parasieten in long, lever en maag. Echter is de ernst van deze afwijkingen niet zodanig groot dat het de dood van dit dier verklaart en door gebrek aan andere bevindingen, blijft het dus onduidelijk wat er met deze bruinvis is gebeurd. UT1760 was een dier in 'rust', dus niet zwanger en niet lacterend. Ze verkeerde in geringe tot slechte voedingstoestand, maar had nog wel wat prooiresten in de maag. Ze had een parasitaire longontsteking, maar omdat het ging om een dier in staat van ontbinding (DCC4), kon de exacte doodsoorzaak niet worden vastgesteld. Bijvangst kon echter niet worden uitgesloten gezien veranderingen in de huid, maar autolyse bemoeilijkte ook de externe beoordeling.

\subsection{Aanvullende testen}

\subsubsection{Bacteriologie en mycologie}

Aanvullend onderzoek naar pathogenen toonde twaalf verschillende soorten; elf bacteriën en één schimmel (Tabel 4.1). Gekweekte organen waaruit de micro-organismen kwamen hadden geassocieerde pathologie en waren daarmee doodsoorzaak gerelateerd (Figuur 4.10). Onder andere Salmonella spp., Neisseria animaloris, Aeromonas hydrophila en Vibrio spp. hebben een zoönotische potentie (Foster et al. 1999; Davison et al. 2010; Haenen et al. 2013; Foster et al. 2019).

Tabel 4.1 Uitslagen bacteriologisch- en mycologisch onderzoek 2019.

\begin{tabular}{|c|c|c|}
\hline Micro-organisme & Orgaan & Aantal dieren \\
\hline \multirow[t]{2}{*}{ Acinetobacter johnsonii } & Lever & 1 \\
\hline & Long & 1 \\
\hline Aeromonas hydrophila & Long & 2 \\
\hline \multirow[t]{4}{*}{ Arcanobacterium spp. } & Huid & 1 \\
\hline & Ruggenmerg & 1 \\
\hline & Borstvin & 1 \\
\hline & Long & 1 \\
\hline Aspergillus fumigatus & Long & 1 \\
\hline \multirow[t]{6}{*}{ Clostridium spp. } & Long & 3 \\
\hline & Lever & 1 \\
\hline & Maag & 1 \\
\hline & Baarmoeder & 1 \\
\hline & Darm & 1 \\
\hline & Huid & 1 \\
\hline \multirow[t]{4}{*}{ Neisseria animaloris } & Long & 3 \\
\hline & Lymfeknoop & 2 \\
\hline & Huid & 2 \\
\hline & Onderhuids abces & 1 \\
\hline Photobacterium damselae & Lever & 1 \\
\hline Salmonella groep B & Long & 1 \\
\hline \multirow[t]{2}{*}{ Shewanella putrefaciens } & Dunne darm & 1 \\
\hline & Long & 1 \\
\hline Streptococcus phocae & Long & 1 \\
\hline
\end{tabular}




\begin{tabular}{lll} 
Micro-organisme & Orgaan & Aantal dieren \\
& Lever & 1 \\
\cline { 2 - 3 } & Lymfeknoop & 1 \\
\cline { 2 - 3 } & Meloen & 2 \\
\cline { 2 - 3 } & Onderhuids abces & 1 \\
\hline Vagococcus fluvialis & Ruggenmerg & 1 \\
\hline Vibrio spp. & Long & 3 \\
\hline
\end{tabular}

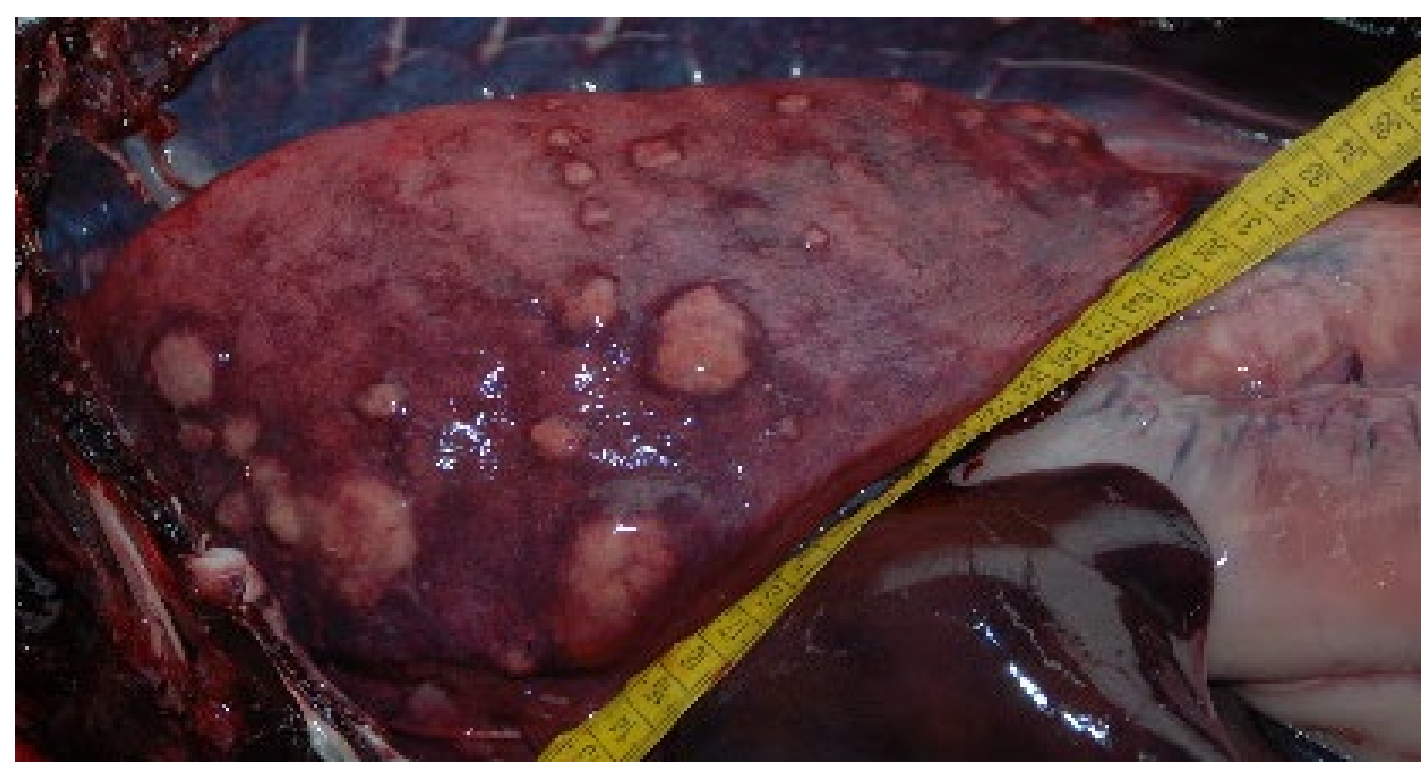

Figuur 4.10 Macroscopisch beeld van de linkerlong van UT1744 met kenmerkende abcessen die gekarakteriseerd worden door goed omschreven, grote massa's (tot $4 \mathrm{~cm}$ in diameter), met caseus exsudaat op sneevlak en een gevolg zijn van een verspreide Neisseria animaloris infectie. Deze infectie is een gevolg van een grijze zeehond beet (zie: Foster et al. 2019 en discussie van deze rapportage).

\subsubsection{Parasitologie}

In Tabel 4.2 is een overzicht te vinden van de parasietenbelasting in de onderzochte bruinvissen. De meeste parasieten werden gevonden in de longen, wat voorkwam bij 68\% (39/57), met middelmatige tot ernstige hoeveelheden in $62 \%$ daarvan (24/39). Daarna volgende infectie van de oren/gehoorgangen, met aanwezigheid van nematoden in 63\% (26/41), met middelmatige tot ernstige hoeveelheden in $31 \%$ daarvan (8/26). Parasieten in de maag(wand) en lever kwamen minder vaak voor ( $51 \%$ en 33\% respectievelijk), met lagere hoeveelheden (Tabel 4.2). Bij twee bruinvissen werd in de darmen een lintworm aangetroffen (UT1739 en UT1745). Walvisluizen werden in actieve, ontstoken huidlaesies bij drie bruinvissen gevonden (UT1745, UT1767 en UT1781).

Tabel 4.2 Parasieten in bruinvissen 2019

\begin{tabular}{lcccc} 
Infectie & $\begin{array}{c}\text { Maag } \\
(\mathrm{n}=57)\end{array}$ & $\begin{array}{c}\text { Longen } \\
(\mathrm{n}=57)\end{array}$ & $\begin{array}{c}\text { Lever } \\
(\mathrm{n}=57)\end{array}$ & $\begin{array}{c}\text { Oor/gehoorgang } \\
(\mathrm{n}=41)\end{array}$ \\
Geen & 28 & 18 & 38 & 15 \\
\hline Mild & 20 & 15 & 16 & 18 \\
\hline Middelmatig & 5 & 15 & 3 & 5 \\
\hline Ernstig & 4 & 9 & 0 & 3 \\
\hline
\end{tabular}




\section{$5 \quad$ Discussie en conclusies}

Postmortaal onderzoek in 2019 van 57 bruinvissen heeft uitgewezen dat de meeste van de onderzochte dieren strandden als gevolg van infectieziekten $(n=17,30 \%)$ of als direct of indirect gevolg van een grijze zeehond aanval $(n=12,21 \%)$. Bijvangst was de doodsoorzaak van zes van de onderzochte dieren (11\%). Dit kon met zekerheid worden gesteld bij één dier, waarbij de bijvangst waargenomen was, en was op basis van de sectie hoogstwaarschijnlijk bij drie bruinvissen en waarschijnlijk bij twee. Daarnaast stierven elf pasgeboren/jonge bruinvissen als gevolg van problemen bij de geboorte en/of onvoldoende voedselopname (19\%), vier andere bruinvissen als gevolg van ernstige vermagering (7\%), twee volwassen vrouwtjes tijdens de bevalling (4\%) en twee bruinvissen door trauma (4\%). Bij één geëuthanaseerde bruinvis kon geen oorzaak voor het levend stranden worden gevonden ( $2 \%$ ) en de doodsoorzaak van twee bruinvissen bleef onduidelijk (4\%).

Deze discussie bestaat uit drie onderdelen. Paragraaf 5.1 gaat in op de in 2019 gevonden doodsoorzaken. Daarbij bediscussiëren we de meest voorkomende doodsoorzaken en nieuwe bevindingen in relatie tot voorgaande jaren en de bestaande literatuur. Paragraaf 5.2 relateert het aantal verzamelde bruinvissen aan het totaalaantal gestrande bruinvissen in de periode 2006-2019. Tot slot volgt in paragraaf 5.3 een vergelijking van doodsoorzaken in de eerdere monitoringsperiode (2008-2013) met het huidige monitoringsproject (2016-2019).

\subsection{Doodsoorzaken bruinvissen 2019}

Infectieziekten is, net als in voorgaande jaren (zie hieronder), de meest voorkomende doodsoorzaakcategorie bij bruinvissen. Naast de categorie infectieziekten, zijn er ook zieke en verzwakte bruinvissen die binnen de groep 'subacuut' of 'chronisch' van de categorie 'grijze zeehond aanval' vallen; dieren die stierven als gevolg van een eerdere aanval, maar zonder grote mutilaties. Dit waren nog eens acht individuen. De infecties die we zien bij dergelijke stranders zijn zeer uiteenlopend, echter meestal ernstig, waarbij meerdere organen belast zijn en waarbij het ziektebeeld zich kenmerkt door grote abcessen en ontstekingen. In 2019 is een tweetal aanvullende wetenschappelijke studies uitgevoerd om de overdraagbaarheid van micro-organismen van de bek van zeehonden naar bruinvissen na een beet nader te onderzoeken. Hierbij lag de focus onder andere op micro-organismen die een zoönotisch potentieel hebben. In een samenwerking met het Departement Infectieziekten en Immunologie (DGK-UU), alsmede de strandingsnetwerken van het Verenigd Koninkrijk, is het (voor bruinvissen) nieuwe besmettingsgevaar met de bacterie $N$. animaloris ontdekt. Foster et al. (2019) publiceerde een casus-serie van bruinvissen met deze infectie als gevolg van grijze zeehond bijtwonden $(n=8)$. Twee bruinvissen met een $N$. animaloris infectie uit 2019 (deze rapportage) brengen het aantal wereldwijd bekende infecties op tien. Gilbert et al. (2020) onderzocht het microbioom in een reeks samples waaronder bijtwonden op bruinvissen, maar ook in de bek van zeehond (onderzoek in samenwerking met Pieterburen). Naast een aantal zeehond-specifieke bacteriële infecties, zoals met $S$. phocae (zie ook Tabel 4.1), werd genetisch materiaal van meerdere zoönotische micro-organismen ontdekt, waaronder Brucella spp., Mycoplasma spp., en Campylobacter spp. Dit toont direct het belang van het tijdig ruimen van gestrande dode bruinvissen door mensen (van het vrijwillige strandingsnetwerk) die bekend zijn met de veiligheids- en hygiëne voorschriften (o.a. het dragen van handschoenen). Hetzelfde geldt voor het hanteren van nog levende bruinvissen, alsmede zeehonden, bijvoorbeeld in de opvangfaciliteiten of tijdens het transport.

Naast de infectieziekten en grijze zeehond aanvallen was de daaropvolgende meest voorkomende diagnose bijvangst. Dieren in de categorie bijvangst worden veelal bestempeld als een goede 'controle' groep, omdat het om een acute sterfte gaat en de kans daarom groter is dat het hier om veelal gezondere dieren gaat ten opzichte van de gestrande dieren (Siebert et al. 2006). Echter in Nederland blijkt dit zeker niet altijd het geval en is een verdere onderverdeling tussen gezonde en zieke dieren binnen de bijvangstcategorie noodzakelijk. Zo werden bij de bijvangstbruinvissen die in 2019 
onderzocht waren, afwijkingen gevonden. Zoals de chronische breuk met ontstekingen in de kaak van het dier wat bij Noordwijk een staand want net was ingezwommen (UT1755), of de ernstige parasitaire longontsteking van UT1748. Het valideren van de gezondheidsstatus van bijgevangen bruinvissen is daarom erg belangrijk voordat deze groep als controlegroep wordt gesteld. Echter 'zekere' bijvangst bruinvissen zijn maar zelden toegankelijk in Nederland. Van 2013-2017 liep een Remote Electronic Monitorings project (REM, voor meer info zie: Scheidat et al. 2018). Tijdens dat project werden acht bijgevangen bruinvissen aangeland. Drie andere bruinvissen werden voor het REM-project aangeland, en met UT1755 (deze rapportage) maakt dat $n=12$. Een artikel met een overzicht van de pathologiebevindingen en het dieet van deze dieren is momenteel in review bij een wetenschappelijk tijdschrift (IJsseldijk et al. in review), maar de conclusies van dit artikel luidden dat bij twee derde van de bijgevangen bruinvissen afwijkingen gevonden werden, welke in $40 \%$ ernstig waren. Deze significante pathologische veranderingen hadden vermoedelijk negatieve effecten op de gezondheid van deze dieren, en waren daardoor wellicht ook een indirecte bijdrage aan de doodsoorzaak. Echter het aantal beschikbare dieren voor deze studie was klein $(n=12)$. Het verkrijgen van meer bijgevangen bruinvissen, bijvoorbeeld bij toekomstige REM-projecten of door verdere samenwerking met de visserijsector, zou helpen om deze resultaten verder te valideren.

Het vaststellen van de oorzaak van stranding bij hele jonge dieren (pasgeboren, of enkele weken tot maanden oud) is vaak lastig, met doodsoorzaken veelal gerelateerd aan acute verhongering, een lage bloedsuikerspiegel en onderkoeling van deze zeer kwetsbare leeftijdsgroep. Verhongering en perinatale sterfte waren dan ook de diagnoses bij respectievelijk 9\% van de bruinvissen in 2019. Meestal blijft het echter onduidelijk wat het onderliggend mechanisme is: een jong dier kan zijn moeder hebben verloren door verstoring, bijvoorbeeld als direct gevolg van aanwezigheid van predatoren of antropogene activiteiten, maar ook kan het zijn dat de moeder niet in staat is voor een jong te zorgen of deze te zogen en pasgeboren dieren worden verstoten en/of zodanig verzwakken dat ze uiteindelijk overlijden.

Het geboorteseizoen van bruinvissen in de Noordzee is mei-augustus. Kalfjes worden geboren met een lengte van rond de $70 \mathrm{~cm}$ en bruinvissen kennen een snelle groei van $>50 \%$ in hun eerste levensjaar (Lockyer 2003). Drie bruinvissen gestrand in juli, hadden lengtes van 91-95 cm. Op basis van deze lengte zouden deze dieren in de categorie juveniel vallen. Het is echter waarschijnlijker dat het bij deze drie bruinvissen om kalfjes van dit jaar zou gaan en wellicht reflecteren deze jonge maar langere dieren vroeggeboortes die al langer de tijd hebben gehad om te groeien tot ze strandden in het midden van het geboorteseizoen. Aan de andere kant kan het ook om late kalfjes van het voorgaande jaar gaan, die door onvoldoende voedselopname een groeiachterstand hebben ontwikkeld. Ter vergelijking: juveniele bruinvissen van rond de één meter lang werden in 2019 voornamelijk in januari-maart gevonden. Daarnaast strandde er in september een bruinvis van $79 \mathrm{~cm}$; een neonaat héél laat of eigenlijk zelfs na het geboorteseizoen. Dergelijke bevindingen kunnen aanwijzingen zijn voor veranderingen in de voortplantingsperiode en/of veranderingen in de lengte bij geboorte; mogelijk beide een gevolg van veranderingen in voedselaanbod (Kasuya 1995). Het aanvullende dieetonderzoek van WMR biedt mogelijk uitkomst in het beter definiëren van het verschil in leeftijdsklasse van deze jonge dieren en het zou dan ook een raadzaam vervolgonderzoek zijn om vast te stellen in welke maanden en op welke lengtes deze jonge dieren overstappen op (gedeeltelijk) vast voedsel waardoor hun moeder-afhankelijkheid minder wordt, wat hun overlevingskans vergroot. Het vaststellen van de lactatieperiode van volwassen vrouwtjes zou hier een onderdeel van moeten zijn.

De andere doodsoorzaken kwamen sporadischer voor. Zo was het opmerkelijk dat er twee volwassen bruinvissen tijdens de bevalling stierven. Dystocia als doodsoorzaak is maar vijf keer eerder als (mogelijke) doodsoorzaak vastgesteld. Trauma werd bij twee dieren als doodsoorzaak opgegeven, en bij een derde dier (UT1730) was trauma de vermoedelijke oorzaak (met de wond als port d 'entree) van een infectie. Oorzaken voor trauma kunnen inter- of intraspecifieke interacties of botsingen met voorwerpen zijn, zoals met een getijdenturbine of een schip, maar ook als gevolg van bijvangst (Leopold \& Scholl 2017). De doodsoorzaak van twee dieren uit 2019 en de strandingsoorzaak van een geëuthanaseerd jong dier bleven onduidelijk; echter een aantal zaken zoals bijvangst, trauma en intraspecifieke interacties konden worden uitgesloten. Ondanks het uitgebreid pathologisch onderzoek blijft het soms alleen mogelijk om bepaalde oorzaken uit te sluiten. 


\subsection{Alle strandingen versus verzamelde bruinvissen}

Naturalis, Leiden houdt het strandingsaantal bij op www.walvisstrandingen.nl. Met 'gestrande bruinvissen' wordt in deze paragraaf gerefereerd aan alle gemelde bruinvissen die in de database van Naturalis zijn opgenomen. In 2019 waren dat 508 gestrande bruinvissen, waarvan zo'n 11\% postmortaal is onderzocht (hierna: verzamelde bruinvissen). In 2019 werden de meeste gestrande bruinvissen in de maand juli gevonden $(n=114)$; gevolgd door september $(n=65)$ en augustus $(n=57)$. De maanden met de minste bruinvisstrandingen waren november $(n=14)$, april $(n=16)$ en december $(n=19)$. De meeste bruinvissen die verzameld werden voor postmortaal onderzoek, strandden ook in juli $(n=11)$, maar gevolgd door januari $(n=10)$ en maart $(n=9)$. Daaruit kunnen we concluderen dat er, net als in voorgaande jaren, proportioneel meer bruinvissen in de winter worden verzameld en onderzocht vergeleken met de zomer, terwijl de meeste gestrande bruinvissen in de zomermaanden worden aangetroffen (zie Figuur 5.1 met data uit de periode 2006-2019, zie ook Figuur B3.1 in Bijlage 3). Dit komt vooral omdat de bruinvissen die stranden in de zomer, over het algemeen vaker in verdere staat van ontbinding verkeren. Dit kan een effect zijn van bijvoorbeeld sneller ontbinden vanwege hogere water- en luchttemperaturen in de zomer. Verschillen in de verspreiding van dieren of temporele verschillen in bedreigingen of doodsoorzaken kunnen echter ook verklaringen zijn; dieren kunnen in de zomerperiode bijvoorbeeld verder van de kust overlijden en dus langer drijven voordat ze stranden, waardoor ze in verdere staat van ontbinding verkeren.

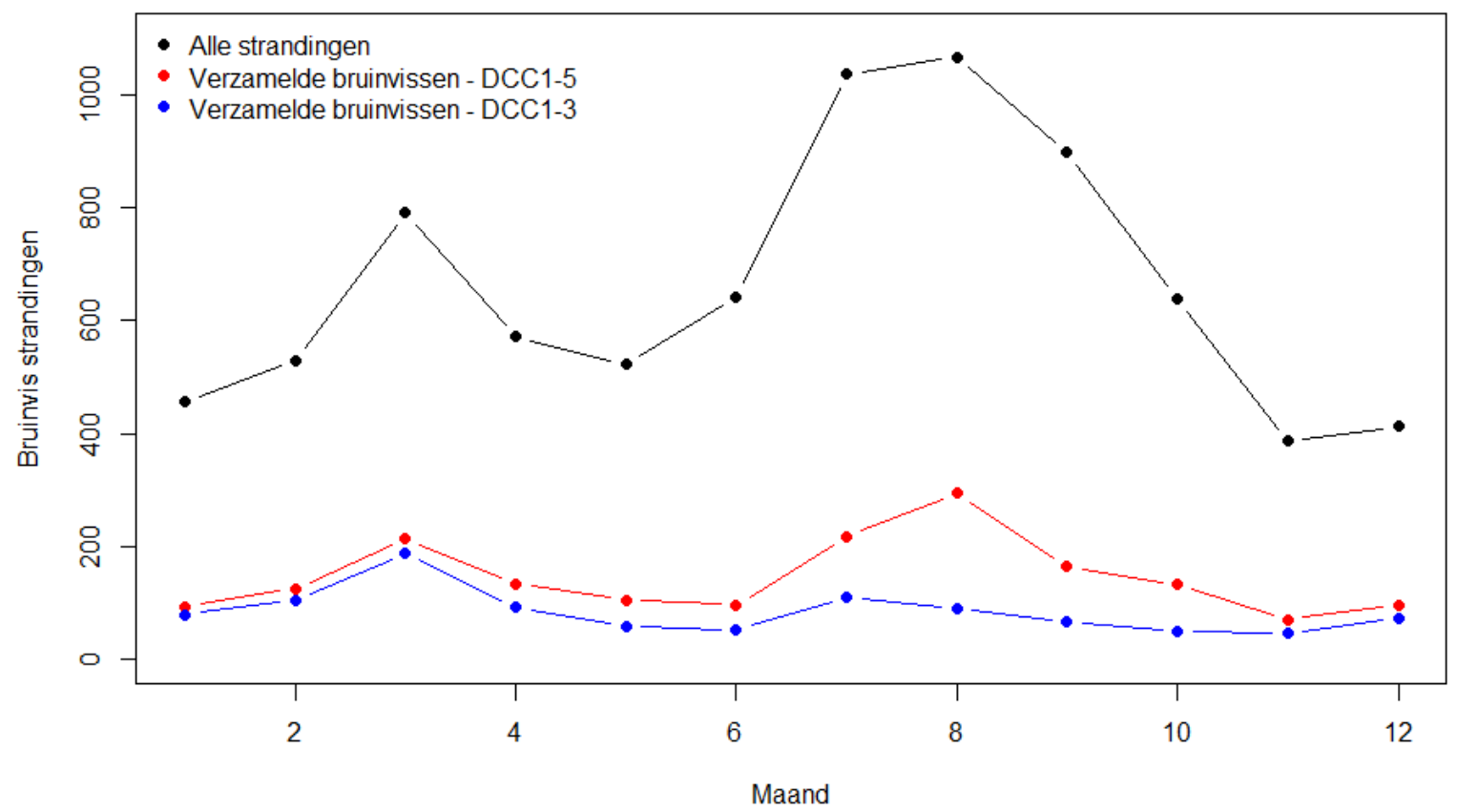

Figuur 5.1 Alle gestrande bruinvissen (zwarte lijn), alle onderzochte bruinvissen in alle staten van ontbinding (rode lijn) en selectie van onderzochte bruinvissen in DCC1-3 (blauwe lijn), som per maand, met data uit de periode 2006-2019. Het aantal gestrande bruinvissen (data voor het genereren van de zwarte lijn) komt van www.walvisstrandingen.nl.

Wanneer we kijken naar de verzamelde bruinvissen ten opzichte van alle gestrande bruinvissen over de periode 2006-2019 zien we ook duidelijk verschillen (Figuur 5.2, zie ook Figuur B3.2 in Bijlage 3). Dit heeft deels te maken gehad met veranderingen in onderzoekfocus en -budget, en is deels een effect van jaarlijkse verschillen in het strandingsaantal. In 2006 en 2007 startte het onderzoek naar gestrande bruinvissen in Nederland (destijds door het Nederlands Instituut voor Zeeonderzoek en IMARES Wageningen UR, het huidige WMR), wat zich in 2008 verplaatste naar de UU. Van 2008-2011 werden alle bruinvissen die nog in redelijke staat verkeerden verzameld. Dieren die verder ontbonden waren (DCC4-5) werden in mindere mate verzameld. In 2011 strandde een groot aantal bruinvissen op de Nederlandse kust. Men verklaarde de zomer van 2011 als een 'unusual mortality event' en daarom werd de intensiteit van het verzamelen van alle gestrande bruinvissen verhoogd, waardoor vooral relatief meer rotte dieren verzameld werden. Een duidelijk verschil tussen de rode en blauwe lijn is zichtbaar in de periode 2011-2013, wat duidt op een groot aantal stranders in staat DCC4-5. In 2011-2013 werden dan ook meer bruinvissen in DCC4-5 onderzocht. De projectverlenging na 2013 
was vertraagd, wat een duidelijke daling betekende in het aantal verzamelde dieren in die periode (2014-2015). Vanaf 2016 valt het postmortaal onderzoek onder de WOT en wordt gefocust op verzameling van voornamelijk DCC1-2, en met regelmaat DCC3 dieren. Dit verklaart het bijna evenredig lopen van de blauwe en rode lijn vanaf het jaar 2016.

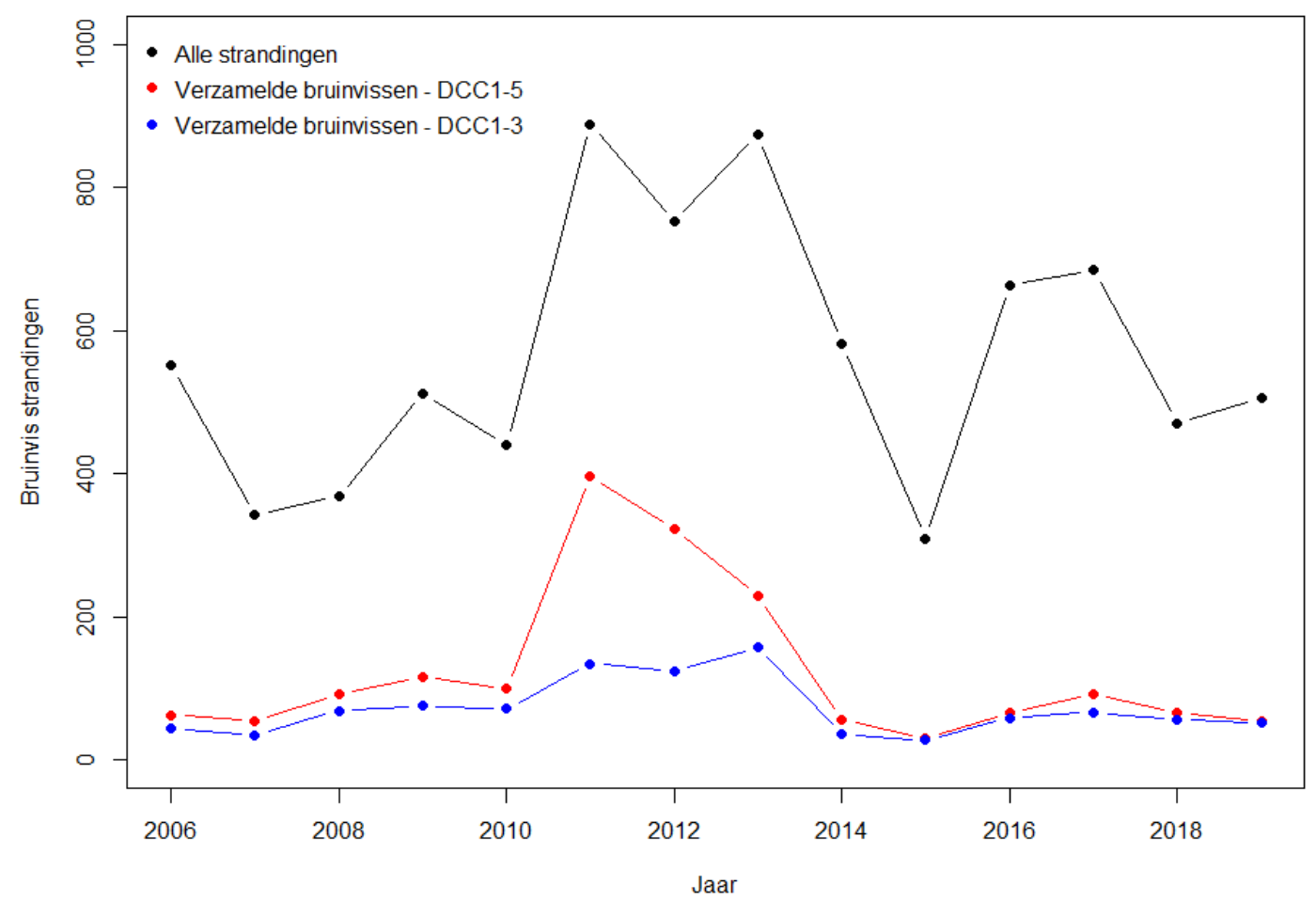

Figuur 5.2 Alle gestrande bruinvissen (zwarte lijn), alle onderzochte bruinvissen in alle staten van ontbinding (rode lijn) en selectie van onderzochte bruinvissen in DCC1-3 (blauwe lijn), som per jaar, met data uit de periode 2006-2019. Het aantal gestrande bruinvissen komt van www. walvisstrandingen.nl.

Wanneer we kijken naar de verschillende gebieden zien we ook duidelijke verschillen tussen de bruinvissen die naar destructie gaan en die voor onderzoek verzameld worden. Zo worden de meeste dode bruinvissen rond de Waddeneilanden gevonden, maar worden er relatief weinig verzameld en onderzocht. De meeste verzamelde dieren komen uit het Deltagebied (Figuur 5.3).

\section{Strandingen per locatie}

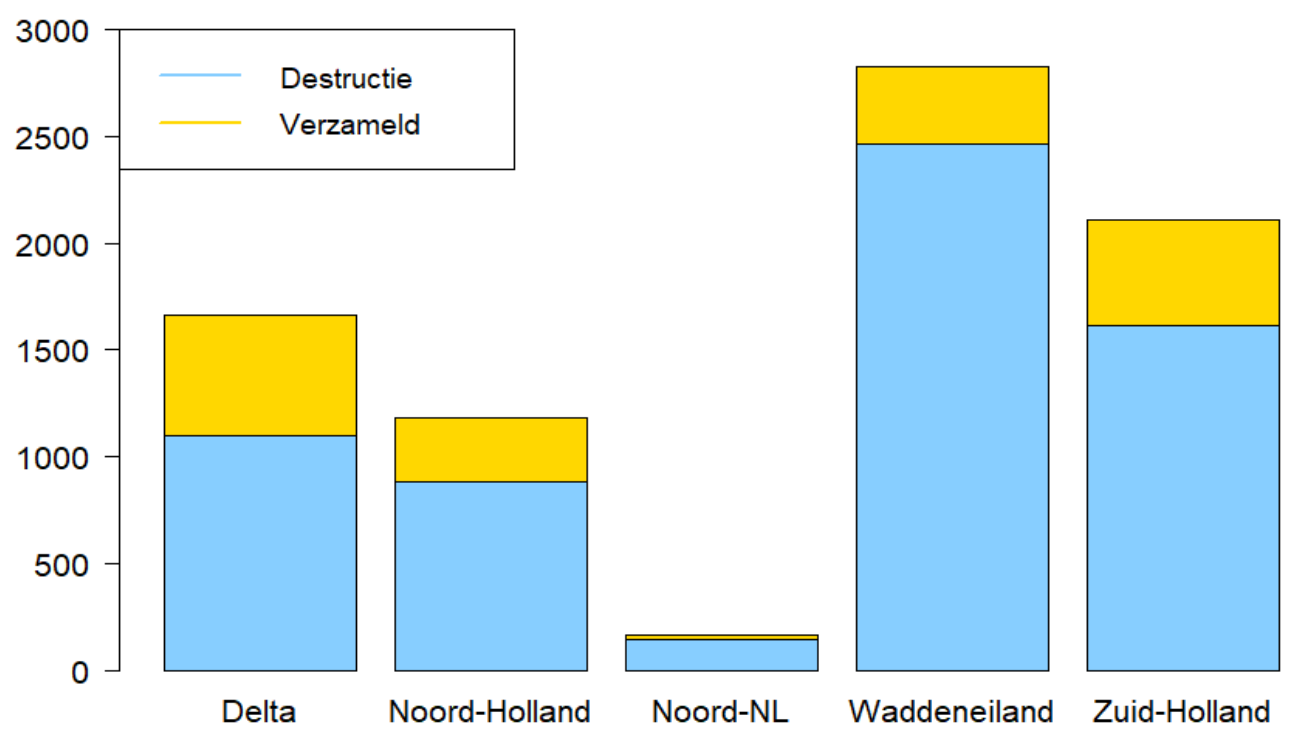

Figuur 5.3 Van 2006-2019 per gebied het aantal gestrande bruinvissen die naar destructie zijn gegaan (blauw) versus het aantal dat verzameld is voor postmortaal onderzoek (geel). 


\subsection{Doodsoorzaken bruinvissen onderzoeksperiodes 2008- 2013 en 2016-2019}

Gezien de verschillen in onderzoeksfocus als direct gevolg van de onderzoekuitbesteding van het ministerie van LNV vergelijken we in deze alinea de doodsoorzaken van de onderzochte bruinvissen in de periode 2008-2013 (hierna: periode 1) met die van de periode 2016-2019 (hierna: periode 2). Een groot verschil in het aantal onderzochte dieren is direct duidelijk: in periode 1 werden 963 gestrande bruinvissen verzameld, terwijl dat in periode 2234 dieren waren. Echter lag het aantal rotte dieren in periode 1 vele malen hoger; 51\% van de bruinvissen in periode 1 verkeerde in DCC4-5 ten tijde van de autopsie, terwijl dat maar $4 \%$ was in periode 2 (en geen DCC5 dieren; Figuur 5.4).

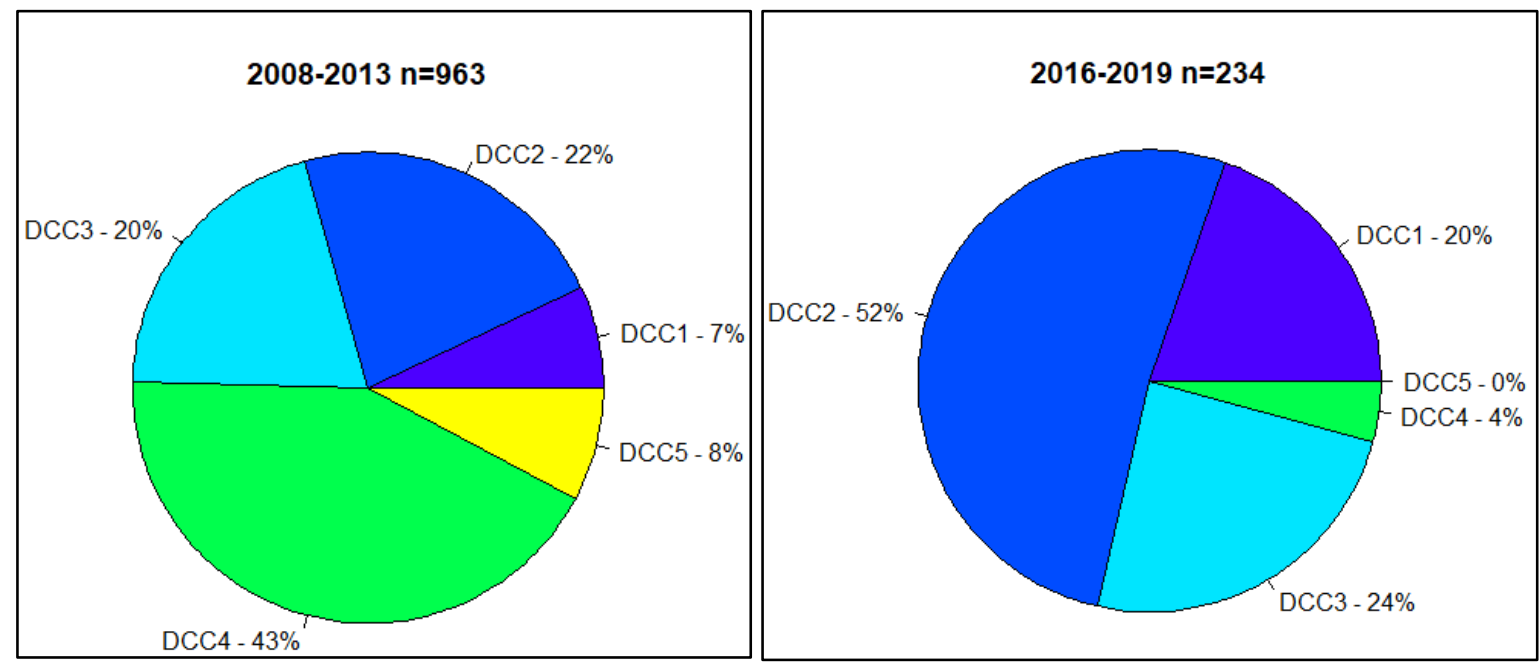

Figuur 5.4 Cirkeldiagrammen met de versheid van de onderzochte bruinvissen in periode 1 (links; 2008-2013) en periode 2 (rechts; 2016-2019). DCC staat voor Decomposition Condition Code met 1 (heel vers) tot en met 5 (in verregaande staat van ontbinding) (zie methoden).

Voor de vergelijking van doodsoorzaken tussen periode 1 en periode 2, waarbij we alleen de DCC1-3 dieren selecteren, zien we een aantal verschillen (Figuur 5.5). Zo is het percentage ziekte omhooggegaan (van $24 \%$ in periode 1 , naar $30 \%$ in periode 2 ); het percentage bijvangst gedaald (van $18 \%$ in periode 1 , naar $11 \%$ in periode 2 ) en het percentage grijze zeehond aanvallen redelijk gelijk gebleven (totaal $25 \%$ in periode 1 en $24 \%$ in periode twee), maar met een verschuiving van acute sterfte naar sterfte als gevolg van bijtwonden (in periode 1 stierf $17 / 25 \%$ acuut, in periode 2 was dit $12 / 24 \%$ ). Vergelijking tussen deze periodes is echter lastig omdat het verschil in de verzamelde dieren (van alle redelijke stranders naar predominant de verse dieren) veranderd is. Zoals in eerdere rapportages aangegeven, zit het verschil vooral in de doodsoorzaken waarvan we weten dat deze vaker dicht op de kust gebeuren (zo strandden zieke dieren vaker levend en ook de grijze zeehond aanvallen gebeuren vermoedelijk dicht onder de kust), versus bijvoorbeeld bijvangst, wat veelal (verder)op zee gebeurt en dieren dus een langere 'aandrijftijd' nodig hebben voordat ze stranden, en de dieren daardoor automatisch vaker in verdere staat van ontbinding verkeren. 


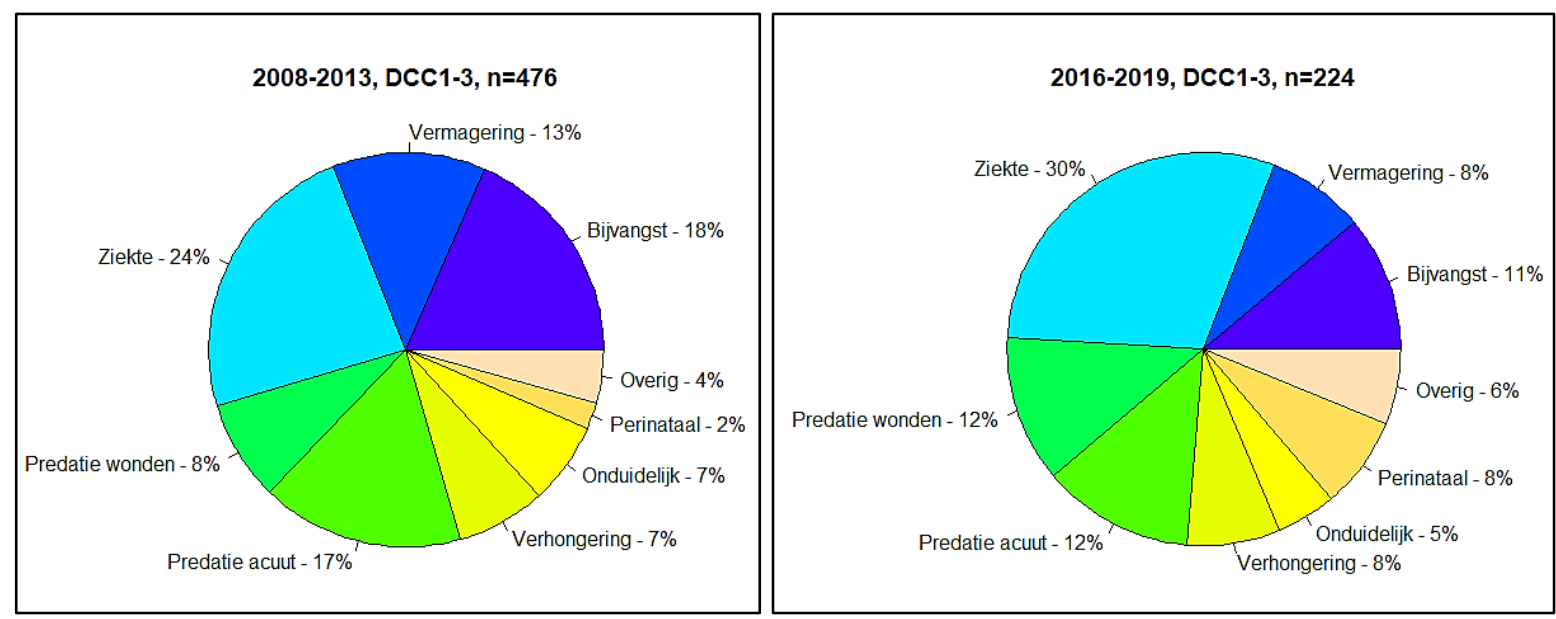

Figuur 5.5 Cirkeldiagrammen met de doodsoorzaken van de onderzochte bruinvissen in periode 1 (links; 2008-2013, DCC1-3) en periode 2 (rechts; 2016-2019, DCC1-3).

Ook lijkt er een leeftijds- en geslachtsspecifieke sterfte te zijn. Het van jaar tot jaar verschillende 'aanbod' aan leeftijdsklasse/geslacht van verzamelde dieren beïnvloedt daardoor de verdeling over de doodsoorzaakcategorieën. Zo stervende neonaten logischerwijs veelal door verhongering en perinatale oorzaken (bijv. na moeilijkheden bij de geboorte), terwijl juveniele dieren naast ziekte, ook vooral door bijvangst, predatie en verhongering sterven. Adulte dieren sterven vooral door infectieziekten. Vooral in 2018 en 2019 lag het aantal volwassen (en dan specifiek vrouwelijke) dieren dat onderzocht werd hoger dan in bijvoorbeeld 2016 en 2017, wat een stijging in het jaarpercentage infectieziekten tot gevolg had.

Bovenstaande voorlopige bevindingen zullen geverifieerd moeten worden door een multivariabele temporele analyse om de eventuele aanwezigheid van leeftijds-, seizoens- en/of locatiespecifieke doodsoorzaken te kunnen bevestigen. Bij een dergelijke analyse moet worden gelet op de representativiteit van de steekproef van verzamelde dieren, die jaarlijks werd genomen en over de tijd verschilde, en waar mogelijk dient gecorrigeerd te worden voor jaarlijkse verschillen. Echter is het belangrijk te vermelden dat er voor de uitvoer van een dergelijke analyse geen ruimte binnen de kaders van het WOT-monitoringsonderzoek is. Hierdoor is het momenteel niet mogelijk om een tijdspad voor het verkrijgen van deze resultaten vast te leggen.

Daarnaast is het goed te vermelden dat hoewel we altijd proberen om een individuele casus op basis van alle bevindingen in één doodsoorzaakcategorie onder te delen, dit meestal niet alle informatie die we over dieren verzamelen goed samenvat. Als voorbeeld de bijvangstdieren of bruinvissen die sterven door predatie, waarbij we soms al aan de buitenkant de kenmerkende netafdrukken en mutilaties kunnen zien en ook al de diagnose bijvangst of predatie zouden kunnen stellen, is het desalniettemin van groot belang om ook bij deze dieren de rol van eventuele onderliggende ziektes of andere afwijkingen vast te stellen. Ten eerste kunnen deze een rol spelen in de kans om (bij)gevangen te worden, maar maakt het histologisch onderzoek ook het verschil in de differentiatie tussen wat voor en na de dood heeft plaatsgevonden. Immers, ook dode bruinvissen kunnen aangevreten worden door zeehonden of in een visnet belanden. Daarnaast lijkt het steeds belangrijker om niet alleen een antwoord te generen op de vraag waaraan een dier uiteindelijk overleden is, maar om ook de gezondheidsstatus van dieren vast te stellen. Om grip te krijgen op de effecten van bedreigingen die veelal extrinsiek en ongrijpbaar zijn, zoals bedreigingen die geen direct letsel veroorzaken als klimaatveranderingen of verstoring, is het belangrijk om verder te kijken dan de doodsoorzaak van dieren alleen. Hoewel het onderzoek hierop ingericht is (bijv. gezien het bijhouden van de weefselbank en het uitvoeren van histologisch onderzoek óók bij dieren waarbij de doodsoorzaak op basis van de macroscopische beoordeling duidelijk is), is de onderzoeksopdracht nog met name gericht op doodsoorzaak. Het (blijven) faciliteren van onderzoek aan een representatieve selectie dieren, het stimuleren van het aanvullen van de weefselbank alsmede het gebruik hiervan voor wetenschappelijk onderzoek, het integreren van verschillende onderzoeken en internationalisering van de monitoring zijn belangrijke stappen om ook in de toekomst te kunnen blijven voldoen aan de vragen vanuit de samenleving en vanuit de verschillende 
beschermingsverdragen; stappen noodzakelijk vooral gezien de stijging in de hoeveelheid antropogene activiteiten in het habitat van de bruinvis. In de herziening van het Bruinvisbeschermingsplan worden aanbevelingen opgenomen over het vervolg van dergelijk onderzoek en rapportage hiervan.

Om het onderzoek naar bruinvisstrandingen in de toekomst voort te kunnen blijven zetten, zullen wij afhankelijk blijven van het vrijwillige strandingsnetwerk maar ook van de registratie van alle bruinvisstrandingen, wat momenteel door Naturalis wordt gedaan. Voor het strandingsnetwerk is geen vergoeding/financiering gerealiseerd; een blijvende kwetsbare situatie die de instandhouding van het monitoringsonderzoek beïnvloed. 



\section{Literatuur}

Aarts G, von Benda-Beckmann AM, Lucke K, Sertlek HÖ, Van Bemmelen R, Geelhoed SCV, ... \& Kirkwood R. (2016). Harbour porpoise movement strategy affects cumulative number of animals acoustically exposed to underwater explosions. Marine Ecology Progress Series, 557, 261-275.

ASCOBANS. (1992). Agreement on the conservation of small cetaceans of the Baltic, North East Atlantic, Irish and North Seas. Toegang via: http://www.ascobans.org/es/documents/agreementtext

Begeman L, IJsseldijk LL, Gröne A. (2014). Postmortaal onderzoek van bruinvissen uit Nederlandse wateren 2009 - 2013. Intern rapport Utrecht Universiteit.

Bernaldo de Quirós YB, Hartwick M, Rotstein DS, Garner MM, Bogomolni A, Greer W, ... \& Moore M. (2018). Discrimination between bycatch and other causes of cetacean and pinniped stranding. Diseases of Aquatic Organisms, 127(2), 83-95.

Bossart GD. (2011). Marine mammals as sentinel species for oceans and human health. Oceanography, 19(2), 134-137.

Camphuysen CJ. (2004). The return of the harbour porpoise (Phocoena phocoena) in Dutch coastal waters. Lutra 47(2), 113-122.

Camphuysen CJ. (2011). Recent trends and spatial patterns in nearshore sightings of harbour porpoises (Phocoena phocoena) in the Netherlands (Southern Bight, North Sea), 1990-2010. Lutra, 54(1), 37-44.

Camphuysen CJ \& Peet G. (2006). Whales and Dolphins of the North Sea. Fontaine Uitgevers.

Camphuysen CJ \& Siemensma ML. (2011). Conservation plan for the harbour porpoise Phocoena phocoena in The Netherlands: towards a favourable conservation status. NIOZ Report 2011-07, Royal Netherlands Institute for Sea Research, Texel, 183 pp.

Dagleish MP, Barley J, Finlayson J, Reid RJ, Foster G. (2008). Brucella ceti associated pathology in the testicle of a harbour porpoise (Phocoena phocoena). Journal of Comparative Pathology 139(1), 5459.

Davison N, Barnett J, Rule B, Chappell S, \& Wise G. (2010). Group B Salmonella in lungworms from a harbour porpoise (Phocoena phocoena). Veterinary Record, 167(9), 351-352.

de Haan D, von Benda-Beckmann S, Geelhoed SCV, \& Lagerveld S. (2015). Potential effects of seismic surveys on harbour porpoises. IMARES Wageningen UR Report number C126/15

Foster G, Patterson IAP, \& Munro DS. (1999). Monophasic group B Salmonella species infecting harbour porpoises (Phocoena phocoena) inhabiting Scottish coastal waters. Veterinary Microbiology, 65(3), 227-231.

Foster G, Whatmore AM, Dagleish MP, Malnick H, Gilbert MJ, Begeman L, ... \& IJsseldijk LL. (2019). Forensic microbiology reveals that Neisseria animaloris infections in harbour porpoises follow traumatic injuries by grey seals. Scientific Reports, 9(1), 1-8.

Geelhoed SCV, Scheidat M, Bemmelen van RSA \& Aarts G. (2013). Abundance of harbour porpoises (Phocoena phocoena) on the Dutch Continental Shelf, aerial surveys in July 2010-March 2011. Lutra 56(1): 45-57.

Geelhoed SCV \& Scheidat M. (2018). Abundance of harbour porpoises (Phocoena phocoena) on the Dutch Continental Shelf, aerial surveys 2012-2017. Lutra 61(1), 127-136.

Gilbert MJ, IJsseldijk LL, Rubio-García A, Gröne A, Duim B, Rossen J, Zomer AL \& Wagenaar JA (2020). After the bite: bacterial transmission from grey seals (Halichoerus grypus) to harbour porpoises (Phocoena phocoena). Royal Society Open Science, 7(5), 192079.

Gilles A, Scheidat M, \& Siebert U. (2009). Seasonal distribution of harbour porpoises and possible interference of offshore wind farms in the German North Sea. Marine Ecology Progress Series, $383,295-307$. 
Haelters J, Kerckhof F, Jacques TG \& Degraer S. (2011). The harbour porpoise Phocoena phocoena in the Belgian part of the North Sea: trends in abundance and distribution. Belgian Journal of Zoology 141(2), 75-84.

Haenen OL, Evans JJ, \& Berthe F. (2013). Bacterial infections from aquatic species: potential for and prevention of contact zoonoses. Revue Scientifique et Technique (International Office of Epizootics), 32(2), 497-507.

Hammond PS, Berggren P, Benke H, Borchers DL, Collet A, Heide-Jørgensen MP, ... \& Øien N. (2002). Abundance of harbour porpoise and other cetaceans in the North Sea and adjacent waters. Journal of Applied Ecology 39(2), 361-376.

Hammond PS, Lacey C., Gilles A, Visquerat S, Borjesson P, Herr H, Macleod K, Ridoux V, Santos MB, Scheidat M, Teilmann J, Vingada J, Oien N. (2017). Estimates of cetacean abundance in European A tlantic waters in summer 2016 from the SCANS -III aerial and shipboard surveys.

Halpern BS, Walbridge S, Selkoe KA, Kappel CV, Micheli F, D'agrosa C, ... \& Fujita R. (2008). A global map of human impact on marine ecosystems. Science, 319(5865), 948-952.

Halpern BS, Frazier M, Potapenko J, Casey KS, Koenig K, Longo C, ... \& Walbridge S. (2015). Spatial and temporal changes in cumulative human impacts on the world's ocean. Nature Communications, 6, 7615.

Herráez P, De Los Monteros AE, Fernández A, Edwards JF, Sacchini S, \& Sierra E. (2013). Capture myopathy in live-stranded cetaceans. The Veterinary Journal, 196(2), 181-188.

IJsseldijk LL, Brownlow AC, \& Mazzariol S (eds.). (2019). Best practice on cetacean post-mortem investigation and tissue sampling. Joint ACCOBAMS and ASCOBANS document: osf.io/zh4ra.

IJsseldijk LL \& Geelhoed SCV. (2016). Fox scavenging mutilations on dead harbour porpoises (Phocoena phocoena). IMARES Wageningen WUR, rapport C036/16.

IJsseldijk LL, Kik MJL, Solé L \& Gröne A. (2017). Postmortaal onderzoek van bruinvissen (Phocoena phocoena) uit Nederlandse wateren, 2016. WOt-technical report 96 ISSN 2352-2739

IJsseldijk LL, ten Doeschate MT, Davison NJ, Gröne A, \& Brownlow AC. (2018). Crossing boundaries for cetacean conservation: Setting research priorities to guide management of harbour porpoises. Marine Policy, 9577-84.

IJsseldijk, L.L., ten Doeschate, M.T.I., Brownlow, A., Davison, N.J., Deaville, R., Galatius, A., Gilles, A., Haelters, J., Jepson, P.D., Keijl, G.O., Kinze, C.C., Olsen, M.T., Siebert, S., Thøstesen, C.B., van den Broek, J., Gröne, A., Heesterbeek, H. (2020). Spatiotemporal mortality and demographic trends in a small cetacean: Strandings to inform conservation management. Accepted for publication at Biological Conservation

Jepson PD, Deaville R, Barber JL, Aguilar À, Borrell A, Murphy S, .. \& Cunningham AA. (2016). PCB pollution continues to impact populations of orcas and other dolphins in European waters. Scientific Reports, 6, 18573.

Kasuya T. (1995). Overview of cetacean life histories: an essay in their evolution. Whales, seals, fish and man, 481.

Kuiken T \& Garcia-Hartmann M, (1993). Proceedings of the first ECS workshop on cetacean pathology: dissection techniques and tissue sampling, Leiden, The Netherlands. ECS Newsletter 17: 1-39.

Leeney RH, Amies R, Broderick AC, Witt MJ, Loveridge J, Doyle J, \& Godley BJ. (2008). Spatiotemporal analysis of cetacean strandings and bycatch in a UK fisheries hotspot. Biodiversity and Conservation, 17(10), 2323.

Leopold MF, Begeman L, Bleijswijk JDL van, IJsseldijk LL, Witte H \& Gröne A. (2015). Exposing the grey seal as a major predator of harbour porpoises. Proceedings of the Royal Society Biology 282: 20142429.

Leopold M \& Scholl M (eds.). (2017). Monitoring getijdenturbines Oosterscheldekering. Jaarrapportage 2017. Wageningen Marine Research, Wageningen UR (University \& Research centre), Wageningen Marine Research rapport C061/17, 43 blz.

Lockyer C. (2003). Harbour porpoises (Phocoena phocoena) in the North Atlantic: Biological parameters. NAMMCO Scientific Publications, 5, 71-89. 
Madsen PT, Wahlberg M, Tougaard J, Lucke K, \& Tyack AP. (2006). Wind turbine underwater noise and marine mammals: implications of current knowledge and data needs. Marine Ecology Progress Series, 309, 279-295.

Maio, E, Begeman L, Bisselink Y, van Tulden P, Wiersma L, Hiemstra S, .. \& van der Giessen J. (2014). Identification and typing of Brucella spp. in stranded harbour porpoises (Phocoena phocoena) on the Dutch coast. Veterinary Microbiology 173(1-2), 118-124.

Moore SE. (2008). Marine mammals as ecosystem sentinels. Journal of Mammalogy, 89(3), 534-540.

Peltier H, Baagøe HJ, Camphuysen CJ, Czeck P, Dabin W, Daniel P, ... \& Ridoux V. (2013). The stranding anomaly as population indicator: the case of harbour porpoise Phocoena phocoena in North-Western Europe. PLoS ONE 8(4), e62180.

Pierce GJ, Santos MB, Murphy S, Learmonth JA, Zuur AF, Rogan E, ... \& Zegers BN. (2008). Bioaccumulation of persistent organic pollutants in female common dolphins (Delphinus delphis) and harbour porpoises (Phocoena phocoena) from western European seas: Geographical trends, causal factors and effects on reproduction and mortality. Environmental Pollution, 153(2), 401415.

Scheidat M, Couperus B, \& Siemensma M. 2018. Electronic monitoring of incidental bycatch of harbour porpoise (Phocoena phocoena) in the Dutch bottom set gillnet fishery (September 2013 to March 2017) (No. C102/18). Wageningen Marine Research.

Siebert U, Tolley K, Vikingsson GA, Olafsdottir D, Lehnert K, Weiss R, \& Baumgärtner W. (2006). Pathological findings in harbour porpoises (Phocoena phocoena) from Norwegian and Icelandic waters. Journal of Comparative Pathology, 134(2-3), 134-142.

ten Doeschate MT, IJsseldijk LL, Hiemstra S, de Jong EA, Strijkstra A, Gröne A \& Begeman L. (2017). Quantifying parasite presence in relation to biological parameters of harbour porpoises Phocoena phocoena stranded on the Dutch coast. Diseases of Aquatic Organisms 127(1), 49-56.

van Beurden SJ, IJsseldijk LL, Cremers HJ, Gröne A, Verheije MH, \& Begeman L. (2015a). Anisakis spp. induced granulomatous dermatitis in a harbour porpoise Phocoena phocoena and a bottlenose dolphin Tursiops truncatus. Diseases of Aquatic Organisms, 112(3), 257-263.

van Beurden SJ, IJsseldijk LL, Ordonez SR, Förster C, de Vrieze G, Gröne A, ... \& Kik M. (2015b). Identification of a novel gammaherpesvirus associated with (muco) cutaneous lesions in harbour porpoises (Phocoena phocoena). Archives of Virology, 160(12), 3115-3120.

van Bleijswijk, J. D., Begeman, L., Witte, H. J., IJsseldijk, L. L., Brasseur, S. M., Gröne, A., \& Leopold, M. F. (2014). Detection of grey seal Halichoerus grypus DNA in attack wounds on stranded harbour porpoises Phocoena phocoena. Marine Ecology Progress Series, 513, 277-281.

von Benda-Beckmann AM, Aarts G, Sertlek HÖ, Lucke K, Verboom WC, Kastelein RA, ... \& Ainslie MA. (2015). Assessing the Impact of Underwater Clearance of Unexploded Ordnance on Harbour Porpoises (Phocoena phocoena) in the Southern North Sea. Aquatic Mammals, 41(4).

Weijs, L., van Elk, C., Das, K., Blust, R., \& Covaci, A. (2010). Persistent organic pollutants and methoxylated PBDEs in harbour porpoises from the North Sea from 1990 until 2008: Young wildlife at risk?. Science of the Total Environment, 409(1), 228-237.

Wisniewska DM, Johnson M, Teilmann J, Siebert U, Galatius A, Dietz R, \& Madsen PT. (2018). High rates of vessel noise disrupt foraging in wild harbour porpoises (Phocoena phocoena). Proceedings of the Royal Society B: Biological Sciences, 285(1872), 20172314.

\section{Nog niet gepubliceerde bronnen:}

IJsseldijk LL, Scheidat M, Siemensma M, Couperus B, Leopold MF, Morell M, Gröne A, Kik MJL. The challenging diagnosis of bycatch: Post-mortem findings in harbor porpoises (Phocoena phocoena) retrieved from gillnets. In review at: Veterinary Pathology

Van den Heuvel-Greve MJ, van den Brink AM, Kotterman M, Kwadijk C, Geelhoed SCV, Murphy S, van den Broek J, Heesterbeek H, Gröne A \& IJsseldijk LL. Polluted porpoises: Generational transfer of contaminates in harbour porpoises from the southern North Sea. In preparation, pending submission 



\section{Verantwoording}

WOt-technical report: 184

Projectnummer: WOT-04-009-047.05

Dit project werd begeleid door Lonneke IJsseldijk (MSc) en Prof. Andrea Gröne (Universiteit Utrecht). De werkwijze werd afgestemd met de opdrachtgever van het ministerie van Landbouw, Natuur en Voedselkwaliteit, en de projectleider van Wageningen Marine Research. Het pathologisch onderzoek werd uitgevoerd volgens internationaal gestandaardiseerde methoden en de betrokken patholoog, Dr. Marja Kik, is een erkend veterinair specialist. De faculteit Diergeneeskunde, afdeling Pathologie heeft een ontheffing voor het vervoeren, afleveren en onder zich hebben van beschermde inheemse zoogdieren (Mammalia), vogels (Aves), reptielen (Reptiles) en amfibieën (Amphibia) en producten van beschermde uitheemse diersoorten, onder artikel 3.6, tweede lid, van de Wet Natuurbescherming met kenmerk Wnb/2018/039 en einddatum 1 februari 2024 ten behoeve van onderzoek en onderwijs.

Naast Anne-Marie Svoboda (ministerie van Landbouw, Natuur en Voedselkwaliteit) en Steve Geelhoed (Wageningen Marine Research) heeft Anne Schmidt, themaleider Informatievoorziening Natuur bij de WOT Natuur \& Milieu deze rapportage beoordeeld.

De auteurs bedanken alle betrokkenen voor hun bijdrage aan het tot stand komen van deze rapportage.

Akkoord Extern contactpersoon

functie: $\quad$ Senior beleidsadviseur mariene natur

naam: $\quad$ Anne-Marie Svoboda

datum: $\quad 09-06-2020$

Akkoord Intern contactpersoon

naam: $\quad$ Anne Schmidt

datum: $\quad$ 19-05-2020 



\section{Begrippenlijst}

Antropogeen: door mensen teweeggebracht

Dystocia: problemen bij geboorte

Etiologie: oorzaakleer

Etiologische agent: de veroorzaker (hier vooral: een bepaald micro-organisme)

Hematoom: plaatselijke ophoping van (gestold) bloed, ook wel: bloeduitstorting

Histologie: weefselleer, ook wel: microscopie

Hypothermie: onderkoeling

Immunosuppressief: onderdrukking van het immuunsysteem

Interspecifieke interacties: interacties tussen soortgenoten

Intraspecifieke interacties: interacties tussen verschillende soorten

De partus/in partu: de bevalling/aan het bevallen

Mutilatie: verminking, verwonding of ernstige beschadiging

Mycologie: onderzoek naar schimmels (fungi)

Necrose: eindstadium van celdood

Nematoden: rondwormen

Neonaat: pasgeborene

Pathologie: ziekteleer

Postmortaal: na de dood

Rostrum: snuit bij zoogdieren 



\section{Bijlage 1 Doodsoorzaak categorieën}

Op alfabetische volgorde:

\section{Bijvangst}

De categorie bijvangst wordt onderverdeeld in vier subcategorieën: zekere bijvangst, zeer waarschijnlijk bijvangst, waarschijnlijk bijvangst en mogelijk bijvangst, om de mate van onzekerheid aan te kunnen geven. Het gebruik van de categorie 'zekere bijvangst' wordt uitsluitend gebruikt voor dieren waarvan bekend is dat ze door vissers uit een net gehaald zijn en waarbij de autopsie heeft kunnen aantonen dat de bijvangst hoogstwaarschijnlijk de doodsoorzaak was. De feitelijke doodsoorzaak in de categorie bijvangst is verstikking in visnetten. Bijvangst is altijd een diagnose die gesteld wordt door o.a. het uitsluiten van andere doodsoorzaken, maar of dit mogelijk is, hangt af van de rottingsstaat van het dier. De aanwezigheid van afdrukken van netten (vaak als inkepingen op de vinnen) is een aanwijzing voor bijvangst. Daarnaast wijst een goede voedingstoestand en onverteerde prooi in de maag op een acute dood, waar bijvangst er één van is. Een andere aanwijzing voor verstikking is aanwezigheid van ernstig longoedeem. Dit laatste is zeer aspecifiek en komt bij veel andere doodsoorzaken ook voor. Bij de diagnoses bijvangst werd eveneens gebruik gemaakt van de 'Review of the Criteria for the Diagnosis of Bycatch' (Kuiken \& García Hartmann 1993). De gerapporteerde 'maaginhoud' bevindingen in deze rapportage zijn tijdens macroscopisch onderzoek geobserveerd. Uitgebreid dieetonderzoek wordt uitgevoerd door Dr. M.F. Leopold (WMR) en elders gerapporteerd.

\section{Grijze zeehond slachtoffers}

De categorie 'aanval door grijze zeehond' is in 2013 toegevoegd naar aanleiding van het vinden van DNA van grijze zeehond in bijtwonden van drie dood gevonden maar hele verse, gemutileerde bruinvissen (Van Bleijswijk et al. 2014). Histologisch onderzoek naar de bijtwonden wonden heeft aangetoond dat deze wonden zijn aangericht terwijl de bruinvis nog in leven was. Naar aanleiding van de karakteristieken van deze wonden is retrospectief gekeken naar de fotodatabase (Leopold et al. 2015). Bruinvissen met soortgelijke verwondingen zijn met de vernieuwde kennis op het gebied van deze interactie tussen twee top predators, geherevalueerd. Op basis daarvan is met terugwerkende kracht de doodsoorzaak van de dieren met vergelijkbare wonden veranderd in grijze zeehond aanval. De categorie 'grijze zeehond slachtoffers' wordt ingedeeld in twee subcategorieën: 'acuut' en 'subacuut/chronisch'. De eerste omvat alle bruinvissen welke direct aan de aanval overleden; die met grote mutilaties en waarbij de wondranden en bijtwonden in het leven zijn aangebracht en geen tekenen van heling tonen. De groep 'subacuut/chronisch' bestaat uit alle bruinvissen welke geen grote mutilaties hebben, maar bijtwonden welke gekenmerkt worden door tekenen van heling of ontsteking. Deze groep heeft de directe aanval overleeft, maar is alsnog overleden ten gevolge van de wonden, e.g. door bloedvergiftiging of moeilijkheden met zwemmen veroorzaakt door de wond (Foster et al. 2019).

\section{Infectieziekten}

Qua ziekteverwekkers kan men denken aan parasieten, bacteriën, schimmels en virussen. Wanneer ontstekingen gevonden worden in organen die ernstig genoeg zijn om de doodsoorzaak te kunnen verklaren, wordt de doodsoorzaak geclassificeerd als 'infectieus'. Vervolgens zal worden geprobeerd om de ziekteverwekker aan te tonen met aanvullend onderzoek, zoals bijvoorbeeld bacterie- of schimmelkweek.

\section{Overig}

Deze categorie is toegevoegd voor de doodsoorzaken anders dan die binnen de andere categorieën passen. Deze doodsoorzaken kwamen veel kleinschaliger voor en zijn daarom samengevoegd in deze categorie. Trauma dieren (zowel stomp trauma als trauma door bijvoorbeeld vermoedelijk scheepsschroeven) vallen onder deze categorie, maar ook bijvoorbeeld volwassen vrouwtjes die sterven tijdens de bevalling (dystocia). 


\section{(Peri-) neonatale sterfte en verhongering}

Pasgeborenen zijn het meest gevoelig voor acute verhongering. Ze hebben een groot lichaamsoppervlakte ten opzichte van hun lichaamsinhoud, en zijn nog immatuur qua metabolisme. Verhongering van pasgeborenen kan veroorzaakt worden door een moeder die te weinig melk produceert, of omdat pasgeborenen en moeder van elkaar zijn gescheiden, bijvoorbeeld door een verstoring in het habitat. Daarnaast zijn kenmerkende bevindingen binnen deze categorie perinatale asfyxie (zuurstofgebrek bij geboorte) of subcutane bloeding en bloedingen in het centrale zenuwstelsel, bijvoorbeeld als gevolg van klemzitten tijdens de partus.

\section{Vermagering}

Vermagering is het proces van langere tijd (dagen/weken tot maanden) niet genoeg voedsel vinden of kunnen vangen, waardoor dieren ernstig vermageren. De diagnose vermagering vormt een diagnostische uitdaging, omdat bij deze dieren vaak geen duidelijke aanwijzingen is voor de exacte doodsoorzaak. Er wordt aangenomen dat bij een blubberdikte van minder dan één centimeter een bruinvis zeer vermagerd is. Hier kunnen bruinvissen aan sterven, bijvoorbeeld door hypothermie (onderkoeling). Vermagering wordt dus toegewezen aan dieren met een zeer dunne blubber laag, waarbij andere doodsoorzaken onwaarschijnlijk of onvindbaar waren. 


\section{Bijlage 2 Basisgegevens bruinvissen 2019}

\begin{tabular}{|c|c|c|c|c|c|c|c|}
\hline UT & Datum & Locatie & $\begin{array}{l}\text { Leeftijds- } \\
\text { klasse }\end{array}$ & Geslacht & DCC & NCC & Lengte \\
\hline 1718 & $5-1-2019$ & Vlieland & J & M & 2 & 3 & 113 \\
\hline 1719 & 3-1-2019 & Neeltje Jans & J & M & 2 & 1 & 108 \\
\hline 1726 & $11-1-2019$ & $\begin{array}{l}\text { Egmond aan } \\
\text { Zee }\end{array}$ & A & M & 2 & 3 & 145.5 \\
\hline 1727 & $13-1-2019$ & IJmuiden & A & v & 2 & 2 & 141 \\
\hline 1728 & $17-1-2019$ & $\begin{array}{l}\text { Egmond aan } \\
\text { Zee }\end{array}$ & A & v & 1 & 2 & 155 \\
\hline 1729 & $14-1-2019$ & Castricum & A & v & 2 & 2 & 145 \\
\hline 1730 & $23-1-2019$ & $\begin{array}{l}\text { Egmond aan } \\
\text { Zee }\end{array}$ & J & M & 2 & 2 & 104 \\
\hline 1734 & $27-1-2019$ & Terschelling & J & M & 1 & 1 & 103 \\
\hline 1735 & $29-1-2019$ & Velsen & J & v & 2 & 6 & 105 \\
\hline 1736 & $7-2-2019$ & Zoutelande & $\mathrm{J}$ & v & 2 & 2 & 96.3 \\
\hline 1737 & $14-2-2019$ & Kerkwerve & J & v & 2 & 2 & 92 \\
\hline 1738 & $18-2-2019$ & Scheveningen & A & M & 1 & 5 & 129.5 \\
\hline 1739 & $28-1-2019$ & Oostkapelle & A & M & 2 & 5 & 140 \\
\hline 1740 & $27-2-2019$ & Terschelling & J & M & 1 & 1 & 102 \\
\hline 1741 & $4-3-2019$ & Schoorl & J & M & 2 & 1 & 113 \\
\hline 1742 & $4-3-2019$ & Castricum & A & M & 1 & 4 & 147 \\
\hline 1743 & $8-3-2019$ & Vlieland & J & M & 2 & 6 & 104 \\
\hline 1744 & $9-3-2019$ & Callantsoog & A & M & 2 & 5 & 144 \\
\hline 1745 & $12-3-2019$ & Katwijk & A & M & 2 & 5 & 141 \\
\hline 1746 & $17-3-2019$ & Zandvoort & J & M & 1 & 4 & 97,7 \\
\hline 1747 & $18-3-2019$ & Renesse & A & v & 2 & 3 & 161.5 \\
\hline 1748 & $21-3-2019$ & Bloemendaal & J & v & 2 & 5 & 103 \\
\hline 1749 & $3-4-2019$ & $\begin{array}{l}\text { Egmond aan } \\
\text { Zee }\end{array}$ & J & M & 2 & 5 & 99 \\
\hline 1750 & $6-4-2019$ & Noordwijk & $\mathrm{J}$ & v & 2 & 3 & 131.5 \\
\hline 1751 & $4-4-2019$ & $\begin{array}{l}\text { Kampersche } \\
\text { Hoek }\end{array}$ & $\mathrm{J}$ & v & 2 & 6 & 96.2 \\
\hline 1752 & $21-4-2019$ & Breskens & A & v & 2 & 3 & 151.5 \\
\hline 1753 & $21-5-2019$ & Heemskerk & A & v & 2 & 4 & 147.5 \\
\hline 1754 & $26-5-2019$ & IJmuiden & $\mathrm{N}$ & M & 2 & 5 & 77 \\
\hline 1755 & $27-5-2019$ & Scheveningen & J & M & 2 & 4 & 115.5 \\
\hline 1756 & $31-5-2019$ & Noordwijk & A & v & 2 & 3 & 151 \\
\hline 1757 & $6-6-2019$ & Katwijk & $\mathrm{N}$ & M & 2 & 6 & 70 \\
\hline 1758 & $9-6-2019$ & Ameland & $\mathrm{N}$ & M & 2 & 2 & 73.5 \\
\hline 1759 & $23-6-2019$ & Kats & $\mathrm{N}$ & v & 1 & 3 & 79 \\
\hline 1760 & $1-7-2019$ & Texel & A & v & 4 & 5 & 148.5 \\
\hline 1761 & 2-7-2019 & Maasvlakte 2 & A & v & 1 & 2 & 175 \\
\hline 1762 & 2-7-2019 & Zierikzee & $\mathrm{N}$ & M & 3 & 5 & 67 \\
\hline 1763 & $1-7-2019$ & Ouddorp & $\mathrm{N}$ & v & 3 & 4 & 86 \\
\hline 1764 & $5-7-2019$ & Wassenaar & J & M & 3 & 3 & 118 \\
\hline 1765 & $7-7-2019$ & Noordwijk & $\mathrm{N}$ & M & 2 & 3 & 91.5 \\
\hline
\end{tabular}




\begin{tabular}{|c|c|c|c|c|c|c|c|}
\hline UT & Datum & Locatie & $\begin{array}{l}\text { Leeftijds- } \\
\text { klasse }\end{array}$ & Geslacht & DCC & NCC & Lengte \\
\hline 1766 & $9-7-2019$ & Langevelderslag & $\mathrm{N}$ & M & 3 & 5 & 91 \\
\hline 1767 & $16-7-2019$ & Wijk aan zee & A & V & 3 & 6 & 150 \\
\hline 1768 & $15-7-2019$ & Kijkduin & $\mathrm{N}$ & M & 2 & 4 & 85 \\
\hline 1769 & $23-7-2019$ & Noordwijk & J & M & 3 & 5 & 95 \\
\hline 1770 & $27-7-2019$ & Noordwijk & $\mathrm{N}$ & V & 3 & 6 & 90 \\
\hline 1771 & $20-8-2019$ & Rockanje & A & V & 4 & 5 & 155 \\
\hline 1772 & $5-3-2019$ & Ouwerkerke & J & M & 3 & 1 & 114 \\
\hline 1773 & 2-9-2019 & Ten Heijde & $\mathrm{N}$ & V & 2 & 6 & 79 \\
\hline 1774 & $9-8-2019$ & $\begin{array}{l}\text { Egmond aan } \\
\text { Zee }\end{array}$ & J & V & 1 & 4 & 93 \\
\hline 1775 & $14-10-2019$ & Westkapelle & $\mathrm{J}$ & M & 2 & 3 & 110.5 \\
\hline 1776 & $27-9-2019$ & Ouddorp & $A$ & $\mathrm{v}$ & 3 & 5 & 145.5 \\
\hline 1777 & $18-9-2019$ & Ameland & A & V & 3 & 6 & 157 \\
\hline 1778 & $25-2-2019$ & Vlissingen & $A$ & $\mathrm{~V}$ & 4 & 6 & 168 \\
\hline 1779 & $19-10-2019$ & 's-Gravenzande & J & M & 2 & 1 & 102 \\
\hline 1780 & $31-10-2019$ & Bruinisse & J & M & 2 & 2 & 101 \\
\hline 1781 & $12-12-2019$ & Wijk aan zee & A & M & 2 & 5 & 140 \\
\hline 1782 & 24-12-2019 & Petten & A & V & 2 & 2 & 146 \\
\hline 1783 & $26-12-2019$ & Terschelling & J & M & 2 & 1 & 127 \\
\hline
\end{tabular}




\section{Bijlage 3 Extra figuren discussie}

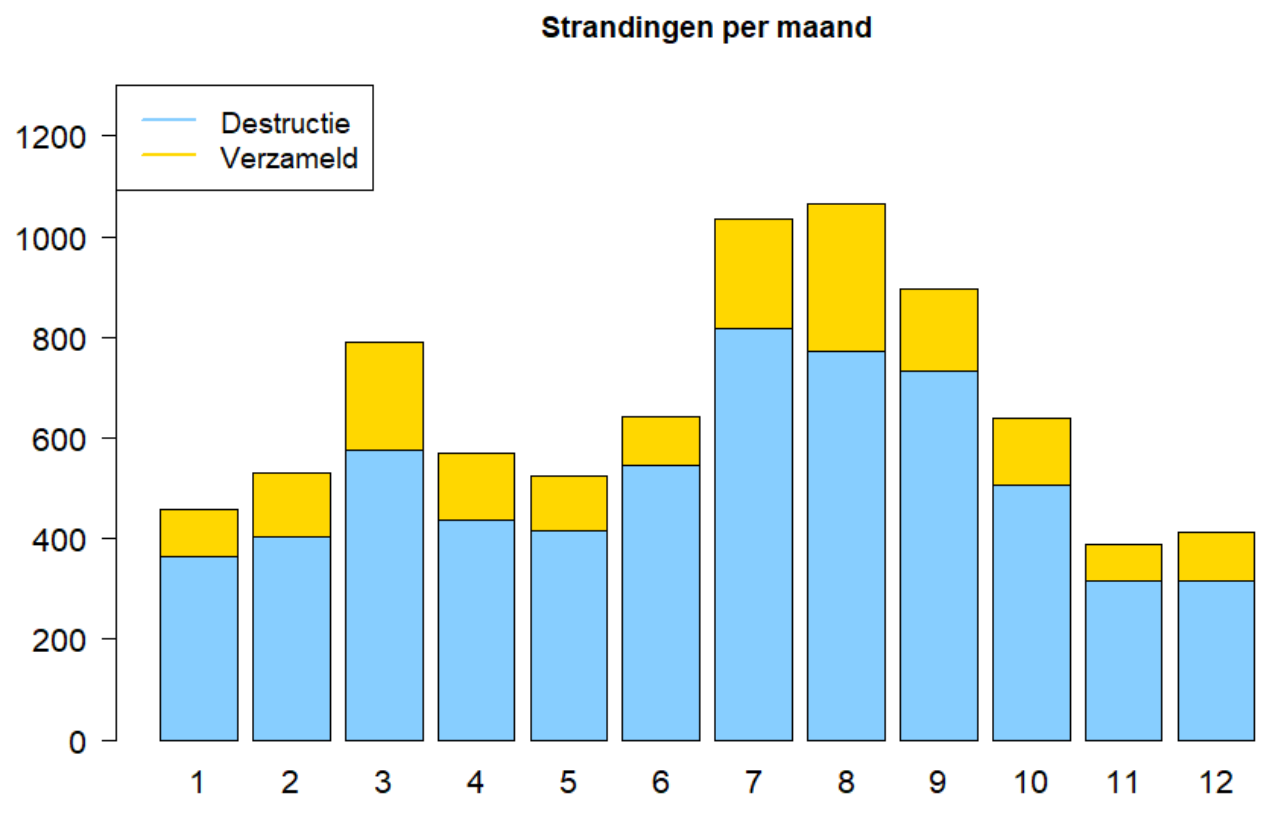

Figuur B3.1 Van 2006-2019 per maand het aantal gestrande bruinvissen wat naar destructie is gegaan (blauw) versus wat verzameld is voor postmortaal onderzoek (geel).

\section{Strandingen 1990 - 2019}

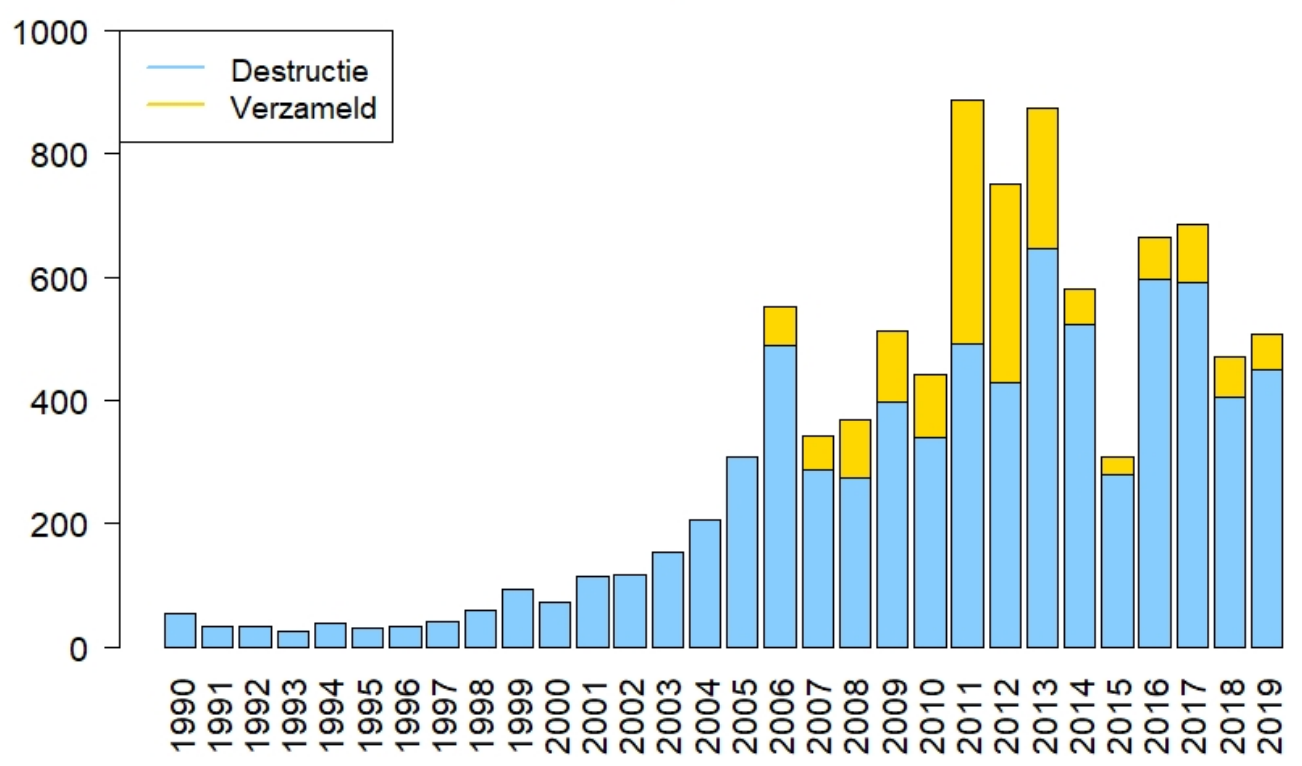

Figuur B3.2 Vanaf 1990 per jaar het aantal gestrande bruinvissen wat naar destructie is gegaan (blauw) versus wat verzameld is voor postmortaal onderzoek (geel) 

146 Arets, E.J.M.M., J.W.H van der Kolk, G.M. Hengeveld, J.P. Lesschen, H. Kramer, P.J. Kuikman \& M.J. Schelhaas (2019). Greenhouse gas reporting of the LULUCF sector in the Netherlands. Methodological background, update 2019.

147 Bruggen, C. van, A. Bannink, C.M. Groenestein, J.F.M. Huijsmans, L.A. Lagerwerf, H.H. Luesink, S.M. van der Sluis, G.L. Velthof \& J. Vonk (2019). Emissies naar lucht uit de landbouw in 2017. Berekeningen met het model NEMA.

148 Lagerwerf, L.A., A. Bannink, C. van Bruggen, C.M. Groenestein, J.F.M. Huijsmans, J.W.H. van der Kolk, H.H. Luesink, S.M. van der Sluis, G.L. Velthof \& J. Vonk (2019). Methodology for estimating emissions from agriculture in the Netherlands. Calculations of $\mathrm{CH} 4, \mathrm{NH} 3, \mathrm{~N} 2 \mathrm{O}$, NOX, NMVOC, PM10, PM2.5 and CO2 with the National Emission Model for Agriculture (NEMA) - update 2019.

149 Bakker, G., M. Heinen, H.P.A. Gooren, W.J.M. de Groot, F.B.T. Assinck \& E.W.J. Hummelink (2019). Hydrofysische gegevens van de bodem in de Basisregistratie Ondergrond (BRO) en het Bodemkundig Informatie Systeem (BIS); Update 2018.

150 IJsseldijk, L.L., M.J.L. Kik, \& A. Gröne (2019). Postmortaal onderzoek van bruinvissen (Phocoena phocoena) uit Nederlandse wateren, 2018. Biologische gegevens, gezondheidsstatus en doodsoorzaken.

151 Daamen, W.P., A.P.P.M. Clerkx \& M.J. Schelhaas (2019). Veldinstructie Zevende Nederlandse Bosinventarisatie (2017-2021); Versie 2.0.

152 Bikker, P., L.B. Šebek, C. van Bruggen \& O. Oenema (2019). Stikstof- en fosfaatexcretie van gangbaar en biologisch gehouden landbouwhuisdieren. Herziening excretieforfaits Meststoffenwet 2019.

153 Berg, F. van den, H. Baveco \& E.L. Wipfler (2019). User manual for SAFE (Select Application date For Evaluation) to support the use of the GEM scenarios for cultivations in glasshouses; Version 1.1

154 Os, J. van, L.J.J. Jeurissen en H.H. Ellen (2019). Rekenregels pluimvee voor de Landbouwtelling; Verantwoording van het gebruik van het Identificatie- \& Registratiesysteem.

155 Brouwer, F. \& D.J.J. Walvoort (2019). Basisregistratie Ondergrond (BRO) Actualisatie bodemkaart; Herkartering van de veengebieden in Eemland

156 Sanders, M.E., R.J.H.G. Henkens \& D.M.E. Slijkerman (2019). Convention on Biological
Diversity; Sixth National Report of the Kingdom of the Netherlands.

157 Kuiters, A.T., G.A. de Groot, D.R. Lammertsma, H.A.H. Jansman, J. Bovenschen, M.C. Boerwinkel \& M. Laar (2019). Genetische monitoring van de Nederlandse otterpopulatie; Ontwikkeling van populatieomvang en genetische status 2018/2019.

158 Sanders, M.E. \& H.A.M. Meeuwsen (2019). Basisbestand Natuur en Landschap.

159 Visser, T., H.A.M Meeuwsen \& Th.C.P. Melman (2019). MNP-(Model for Nature Policy) Agrarisch; Uitwerking voor scenario's uit de Natuurverkenning 2020.

160 Jong, A. de, A. Poot \& P.I. Adriaanse (2019). Impact analysis for the purpose of the introduction of DROPLET version 1.3.2.

161 Westerink, J., T.A. de Boer, M. Pleijte \& R.A.M. Schrijver (2019). Kan een goede boer natuurinclusief zijn?; De rol van culturele normen in een beweging richting natuurinclusieve landbouw.

162 Buijs, A.E., F.G. Boonstra (2020). Natuurbeleid betwist; Visies op legitimiteit en natuurbeleid.

163 Haas, W. de, J.L.M. Donders, T.J.M. Mattijssen (2019). Natuur in conflict; Botsende waarden, waarheden en belangen in het natuurbeheer.

164 Berg, F. van den, A. Tiktak, D. van Kraalingen \& J.J.T.I. Boesten (2019). User manual for FOCUSPEARL version 5.5.5.

165 Glorius, S.T., A. Meijboom, J. Schop \& J.T. van der Wal (2019). Ontwikkeling van enkele droogvallende mosselbanken in de Nederlandse Waddenzee; situatie 2018.

166 Pedroli, B, During, R. (2019). De paradox van een maakbare natuur - ingebakken en omstreden; Betekenis culturele identiteit voor draagvlak natuurbeleid en -beheer.

167 Walvoort, D.J.J., M. Knotters, F.M. van Egmond (2019). Interpolatie, aggregatie en desaggregatie van ruimtelijke bodemgegevens in de Basisregistratie Ondergrond (BRO).

168 Arets, E.J.M.M., J.W.H van der Kolk, G.M. Hengeveld, J.P. Lesschen, H. Kramer, P.J. Kuikman \& M.J. Schelhaas (2020). Greenhouse gas reporting of the LULUCF sector in the Netherlands. Methodological background, update 2020.

170 Bos-Groenendijk, G.I., C.A.M van Swaay (2020). Habitatrichtlijnrapportage 2019: Annex B Habitatrichtlijnsoorten; Achtergronddocument.

171 Janssen, J.A.M. (red.), R.J. Bijlsma (red.), G.H.P. Arts, M.J. Baptist, S.M. Hennekens, B. de 
Knegt, T. van der Meij, J.H.J. Schaminée, A.J. van Strien, S. Wijnhoven, T.J.W. Ysebaert (2020). Habitatrichtlijnrapportage 2019: Annex $D$ Habitattypen. Achtergronddocument.

172 Van Kleunen, A., M. van Roomen, E. van Winden, M. Hornman, A. Boele, C. Kampichler, D. Zoetebier, H. Sierdsema \& C. van Turnhout (2020). Vogelrichtlijnrapportage 2013-2018 van Nederland - status en trends van soorten.

173 Glorius, S.T., A. Meijboom (2020). Ontwikkeling van de bodemdiergemeenschap in de geulen van referentiegebied Rottum; Tussenrapportage 13 jaar na sluiting (najaar 2018).

174 Kuindersma, W., D. van Doren, R. Arnouts, D.A. Kamphorst, J.G. Nuesink, E. de Wit-de Vries (2020). Realisatie Natuurnetwerk door provincies. Achtergrondstudie bij de Tweede Lerende Evaluatie Natuurpact.

175 Bouwma, I.M., D.A. Kamphorst, D. van Doren, T.A. de Boer, A.E. Buijs, C.M. Goossen, J.L.M. Donders, J.Y. Frissel, S. van Broekhoven (2020). Provinciaal beleid voor maatschappelijke betrokkenheid bij natuur het beleid nader bekeken in 8 casussen. Achtergrondstudie bij de Tweede Lerende Evaluatie Natuurpact.

176 Gerritsen, A.L., H. Agricola, C. Aalbers, J. van Os (2020). Natuur en landbouw verbinden. Achtergrondstudie bij de Tweede Lerende Evaluatie Natuurpact.

177 Brouwer, F., D.J.J. Walvoort (2020). Basisregistratie Ondergrond (BRO) Actualisatie bodemkaart. Herkartering van de veengebieden aan de flanken van de Utrechtse Heuvelrug.

178 Bruggen, C. van, A. Bannink, C.M. Groenestein, J.F.M. Huijsmans, L.A. Lagerwerf, H.H. Luesink, G.L. Velthof \& J. Vonk (2020). Emissies naar lucht uit de landbouw, 1990-2018; Emissies van ammoniak, stikstofoxide, lachgas, methaan, niet-methaan vluchtige organische stoffen, fijnstof en koolstofdioxide uit kalkmeststoffen - Berekeningen met het model NEMA.

179 Knegt, de B., M. Pleijte, E. de Wit-de Vries, I. Bouwma, F. Kistenkas, W. Nieuwenhuizen (2020). Samenhang Klimaatakkoord en natuurbeleid. Proces en implementatie van het Klimaatakkoord door provincies en maatschappelijke partijen en de potentiële effecten op biodiversiteitsdoelen van de Vogelen Habitatrichtlijn.

180 Mattijssen T.J.M., M. Pleijte, J. Dengerink, T. Koster, M. Visscher (2020). Indicatoren voor burgerbetrokkenheid bij natuur: een zoektocht naar nieuwe aanknopingspunten voor monitoring.

183 Koffijberg K., P. de Boer, S.C.V. Geelhoed, J. Nienhuis, K. Oosterbeek, J. Postma (2020). Broedsucces van kustbroedvogels in de Waddenzee in 2018

184 IJsseldijk, L.L., M.J.L. Kik, L. van Schalkwijk, A. Gröne (2020). Postmortaal onderzoek van bruinvissen (Phocoena phocoena) uit Nederlandse wateren, (2019). Biologische gegevens, gezondheidsstatus en doodsoorzaken. 



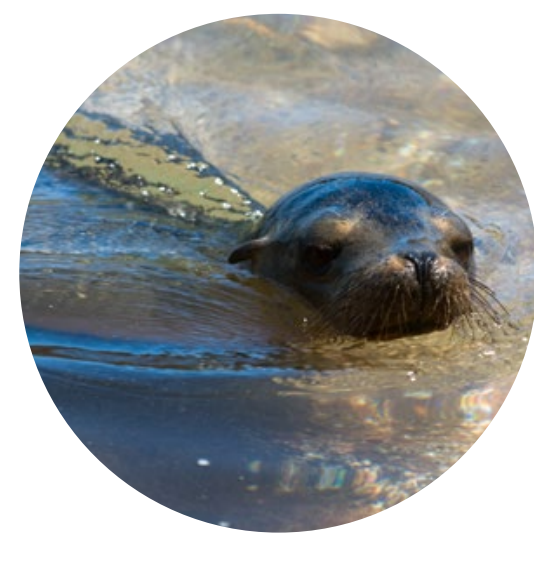

Thema Informatievoorziening Natuur Wettelijke Onderzoekstaken Natuur \& Milieu

Postbus 47

6700 AA Wageningen

T (0317) 485471

E info.wnm@wur.nl

ISSN 2352-2739

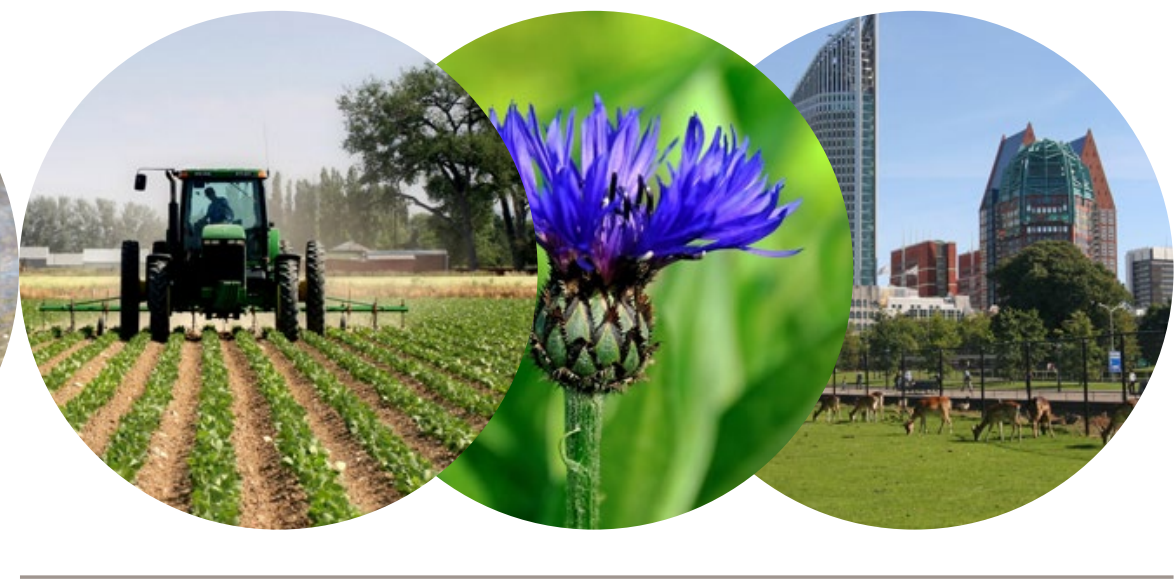

De missie van Wageningen University \& Research is 'To explore the potential of nature to improve the quality of life'. Binnen Wageningen University \& Research bundelen 9 gespecialiseerde onderzoeksinstituten van Stichting Wageningen Research en Wageningen University hun krachten om bij te dragen aan de oplossing van belangrijke vragen in het domein van gezonde voeding en leefomgeving. Met ongeveer 30 vestigingen, 5.000 medewerkers en 10.000 studenten behoort Wageningen University \& Research wereldwijd tot de aansprekende kennisinstellingen binnen haar domein. De integrale benadering van de vraagstukken en de samenwerking tussen verschillende disciplines vormen het hart van de unieke Wageningen aanpak. 